• 研究报告・

\title{
中国雪豹的威胁与保护现状
}

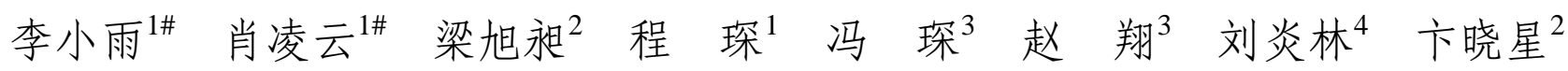
何 兵 ${ }^{5}$ 张常智 $^{5}$ Justine Shanti Alexander ${ }^{6}$ 邢 点 ${ }^{7}$ 黄亚慧 $^{7}$ 阿旺久美 ${ }^{8}$ 谢然尼玛 $^{9}$ 宋大昭 ${ }^{4}$ 黄巧雯 $^{4}$ 扎西桑俄 $^{10}$ 彭 奎 $^{11}$ 尹 杭 ${ }^{12}$ 连新明 $^{13}$ 杨 欣 ${ }^{14}$ 李 輀 ${ }^{1}$ 施小刚 ${ }^{15}$ 杨创明 ${ }^{16}$ 吕 植 ${ }^{*}$

1 (北京大学生命科学学院, 北京 100871) 2 (国际野生生物保护学会, 北京 100101) 3 (山水自然保护中心，北京 100871) 4 (中国猫科动物保护联盟, 北京 101121)

5 (世界自然基金会, 北京 100037) 6 (Snow Leopard Trust, Seattle WA 98103, USA)

7 (荒野新疆, 乌鲁木齐 830000) 8 (原上草自然保护中心, 西宁 810012)

9 (治多县索加乡人民政府, 青海玉树 815400) 10 (年保玉则生态环境保护协会, 青海果洛 624700)

11 (永续全球环境研究所, 北京 100600) 12 (雪境生态宣传教育与研究中心, 西宁 810007)

13 (中国科学院西北高原生物研究所, 西宁 810008) 14 (四川省绿色江河环境保护促进会, 成都 610041)

15 (四川卧龙国家级自然保护区, 四川汶川 623006) 16 (四川贡嘎山国家级自然保护区, 四川甘孜 626000)

摘要: 大部分保护机构只有能力在特定种群层面上保护大型食肉动物, 而物种的灭绝风险却是在全球尺度进行评 估的。因此, 要填补这一尺度断层, 多机构的工作与意见汇总非常必要。本研究综合了文献和18家中国雪豹 (Panthera uncia)研究与保护机构共24位一线工作人员提供的信息, 经过两次集体讨论和填写评分表格的方式, 识 别出21种威胁因素, 在全国层面和青海、西藏、新疆、四川和甘肃 5 个主要雪豹分布省区层面对威胁进行了排序, 并 汇总了各保护机构实施的17项保护行动, 以及各项行动所应对的威胁。全国评分前三的威胁依次是基层保护部门 能力不足(9.5分)、气候变化(8.0分)、当地社区保护动力不足(6.8分), 不同省区的威胁排序则体现出很大差异性。 其中, 目前仍没有任何行动措施应对气候变化。虽然已有一些保护行动来应对基层保护能力不足和当地社区保护 动力不足的问题, 如保护区能力建设、开展社区监测等, 但行动的覆盖尺度仍远远不够。

关键词：雪豹; 中国; 威胁评估; 专家意见; 保护行动

\section{Ongoing threats and the current status of snow leopard conservation in China}

Xiaoyu $\mathrm{Li}^{1 \#}$, Lingyun Xiao ${ }^{1 \#}$, Xuchang Liang ${ }^{2}$, Chen Cheng ${ }^{1}$, Chen Feng ${ }^{3}$, Xiang Zhao ${ }^{3}$, Yanlin Liu $^{4}$, Xiaoxing Bian', Bing $\mathrm{He}^{5}$, Changzhi Zhang, Justine Shanti Alexander ${ }^{6}$, Rui Xing ${ }^{7}$, Yahui Huang, Awangjiumei $^{8}$, Xierannima ${ }^{9}$, Dazhao Song ${ }^{4}$, Qiaowen Huang ${ }^{4}$, Zhaxisange $^{10}$, Kui Peng ${ }^{11}$, Hang Yin ${ }^{12}$, Xinming Lian ${ }^{13}$, Xin Yang ${ }^{14}$, Sheng $\mathrm{Li}^{1}$, Xiaogang Shi ${ }^{15}$, Chuangming Yang ${ }^{16}$, Zhi Lü ${ }^{1 *}$

1 College of Life Sciences, Peking University, Beijing 100871

2 Wildlife Conservation Society, Beijing 100101

3 Shan Shui Conservation Center, Beijing 100871

4 Chinese Felid Conversation Alliance, Beijing 101121

5 World Wide Fund for Nature, Beijing 100037

6 Snow Leopard Trust, Seattle WA 98103, USA

7 Wild Xinjiang, Urumqi 830000

8 Plateau Nature Conservancy, Xining 810012

9 People's Government of Suojia Township, Zhiduo County, Yushu, Qinghai 815400

10 Nyanpo Yutse Conservation Association, Golog, Qinghai 624700

11 Global Environmental Institute, Beijing 100600

收稿日期: 2019-01-31; 接受日期: 2019-08-31

\# 共同第一作者 Co-first authors

* 通讯作者 Author for correspondence. E-mail: luzhi@pku.edu.cn 
12 Gangri Neichog Research and Conservation Center, Xining 810007

13 Northwest Institute of Plateau Biology, Chinese Academy of Sciences, Xining 810008

14 Greenriver Environmental Protection Association of Sichuan Province, Chengdu 610041

15 Wolong National Nature Reserve, Wenchuan, Sichuan 623006

16 Gongga Mountain National Nature Reserve, Garzê, Sichuan 626000

\begin{abstract}
When working with widespread large carnivores, most conservation organizations can only perform direct conservation actions for a specific population, but the extinction risk of a species is evaluated at a global scale. Here, we aim to bridge this impact gap by assessing the work and opinions from many organizations. We combines knowledge from scientific literature with the observations of 24 front-line staff working at 18 Chinese snow leopard research and conservation organizations. Through attending two group-meetings and by filling in threat-scoring spreadsheets, we identified 21 threats and ranked them at both the national and provincial levels. The five main snow leopard distribution provinces are Qinghai, Tibet, Xinjiang, Sichuan and Gansu. Also, we analyzed 17 conservation actions conducted by these conservation organizations, as well as the threats these actions attempted to address. The top three threats in China are the insufficient capacity of local conservation departments (9.5 points), climate change (8.0 points), and the lack of conservation incentive among local communities (6.8 points), although large differences exist between provinces. There is currently no action being taken in response to climate change. Although some conservation actions have addressed the insufficient capacity of local conservation departments and the lack of conservation awareness in local communities, such as by building up the capacity of conservation areas and monitoring by communities, respectively, the spatial coverage of these actions is still far from sufficient.
\end{abstract}

Key words: snow leopard; China; threat assessment; expert opinion; conservation actions

近几十年来，随着生物多样性保护的热度持续 增长, 物种濒危原因与保护对策研究日益受到全世 界的关注(Ma \& Qian, 1998)。为了更加有效地开展 保护行动, Salafsky和Margoluis (1999)提出了广义 的保护行动概念模型: (1)识别保护目标, 提出保护 愿景; (2)识别保护目标所面临的威胁, 包括来自内 部和外部的直接威胁及间接威胁; (3)提出针对上述 威胁的应对行动。虽然模型是普适的, 但目前大部 分保护机构只有在某个特定种群层面上对大型食 肉动物进行保护的能力, 而物种的灭绝风险却是在 全球尺度进行评估的(Donlan et al, 2010)。全球尺度 的评级放到实地用处不大, 而实地的经验又无法有 效推广到全球层面的物种灭绝风险评估上。因此, 要填补这一信息鸿沟, 多机构的工作与意见汇总非 常必要。

雪豹(Panthera uncia) 被世界自然保护联盟 (International Union for Conservation of Nature, IUCN) 评为易危(VU), 物种的存续仍然受到威胁 (McCarthy et al, 2017)。2013年, Snow Leopard Survival Strategy (SLSS, Jackson et al, 2013)评估了 全球雪豹面临的威胁。在中国, 缺乏有效的保护力 量和跨境合作, 家畜数量增长、人兽冲突加剧, 以 及大型发展项目和矿业开发是雪豹面临的主要威

\section{胁。China Snow Leopard Conservation Action Plan} (Revised Manuscript) (China Forestry Administration, 2013)也指出，放牧导致的栖息地被侵占、草场退 化、猎物减少、气候变化、非法采矿和道路建设, 以 及保护力度欠缺等是中国雪豹面临的主要威胁。然 而，雪豹所面临威胁的性质、程度及其影响在不同 地区表现出差异性(Jackson et al, 2013)。两次世界范 围的雪豹威胁评估已从国家尺度勾勒出大致的威 胁排序的框架, 但由于我国各省区情况差别较大 (EIA, 2008; Xu et al, 2008; Peng, 2009; Ma, 2012; Chen et al, 2016), 要因地制宜实施保护策略仍需要 更加细致的威胁评估。

中国拥有全世界60\%的雪豹适宜栖息地(Jackson et al, 2013), 中国的雪豹保护对全球雪豹保护意 义重大。过去20年来, 中国的雪豹保护热度不断提 升, 有越来越多的民间力量自发参与其中, 包括社 会公众、民间组织、科研工作者以及当地社区等, 在 政府的主导下, 有效补充了保护地资源与人力的不 足。在为这些保护进展感到欣喜之余, 还需要及时 梳理和总结这些保护工作是否能有效应对重要的 威胁, 确定中国雪豹保护的下一步努力方向, 这对 全球雪豹保护具有重要意义。

社会科学和风险评估部门广泛运用的专家意 
见汇总方法(Kerr，1996)，近年来被越来越多地应用 到保护工作中来, 以期在数据缺乏的情形下指导决 策(Aipanjiguly et al, 2003; Martin et al, 2005)。为了 收集现阶段雪豹受到的威胁和正在进行的保护行 动, 本研究由正在中国进行雪豹保护与研究工作的 一线人员参与, 采用统一评分标准打分的方式, 首 次在省区尺度得到了雪豹面临的威胁及其排序, 并 收集了现有的雪豹保护行动和相关保护政策, 梳理 了这些行动与政策所应对的威胁, 以期对未来雪豹 的保护行动计划有所裨益。

\section{研究方法}

\section{1 威胁识别}

首先, 从Snow Leopard Survival Strategy (Jackson et al, 2013)中获取国际公认的雪豹威胁因素, 由 来自18家中国雪豹研究与保护机构的24位一线工 作人员 (研究工作分布于雪豹分布的 5 个主要省区, 即青海、西藏、四川、新疆和甘肃)进行两次集中讨 论, 结合实际情况篮选并确定国内存在的威胁因 素。其次, 检索涉及各威胁因素的文献, 列出这些 威胁因素的具体案例。最后, 请所有参与讨论的成 员补充文献中未记载但实际存在的各地案例。

\section{2 威胁排序}

参照IUCN和国际鸟类联盟(BirdLife International)制定的威胁评估标准，从“面积”、“强度”和 “急迫性” 3 个维度设计统一的评分表格, 请机构工 作人员分别对自己开展研究工作所在省/自治区的 威胁因素进行评分 (Salafsky \& Margoluis, 1999; Donlan et al, 2010)。“面积”代表此威胁所影响区域 的大小, “强度”代表该威胁对所在区域造成影响的 大小, “急迫性”代表该威胁的紧急程度。评分按影响 从小到大，从1-5递增。三者加和是该威胁的总分。 同一个省区的评分经过平均后，得到该省区的最终 威胁评分表。将各省区雪豹适宜栖息地面积占全国 总栖息地比例作为权重(雪豹栖息地面积来自 Li et $\mathrm{al}$, 投稿中), 乘以该省区某威胁的评分, 加权后结 果相加, 作为各威胁因素的全国总评分。

\section{3 保护现状评估与典型保护案例收集}

我们根据威胁因素设计了统一的表格, 请各雪 豹保护机构工作人员罗列并汇总在各自工作区域 开展过或正在开展的雪豹保护行动, 以及国家层 面、各级政府、保护区惠及雪豹的政策、项目等，并
勾选各保护行动所应对的威胁。在每项保护行动中, 挑选出一个最具代表性的案例(国家政策除外), 由 该案例的实施方提供具体的描述文字。

\section{结果}

\section{1 威胁识别}

共识别出威胁 21 种，可分为 4 大类：对雪豹个 体的捕杀或抓捕、栖息地和猎物相关威胁、政策和 认知不足、间接威胁(表1)。通过文献检索与各一线 工作人员补充, 收集到的国内具体威胁案例详见附 录 1 。

\section{2 威胁排序}

最终共有来自 5 个省/自治区、代表10家雪豹研 究与保护机构的 12 位一线工作人员参与了威胁评 估(原始评分结果见附录2)。根据评分结果，我们对 全国和每个省区内的威胁进行了排序(图1)。

青海省的威胁评分整体较低，评分前三位的威 胁依次是：基层保护部门能力不足(9.7分)、流浪狗 袭击雪豹及其猎物(8.3分)、栖息地破碎化(8.0分)。 西藏自治区整体的威胁评分最低，评分最高的威胁 为气候变化(8.0分), 其次是基层保护部门能力不足 (6.0分), 第三是家畜竞争导致的猎物种群减少(5.0 分)。就四川省而言，基层保护部门能力不足与人口 增长和贫困的评分并列第一 (13.5分), 其次是缺乏 跨省(境)合作(11.0分)和家畜竞争导致的猎物种群 减少(10.0分)。新疆排名最高的威胁是基层保护部门 能力不足，以及缺乏跨省(境)合作(13.5分，并列第 一), 其次是猎物疾病(12.0分)和当地社区保护动力 不足(10.5分)。甘肃省评分前三的威胁分别是基层保 护部门能力不足(10.2分), 盗猎和误杀导致的猎物 种群减少(9.2分)及下毒、下套等导致的误杀(9.1分)。 内蒙古自治区和云南省缺乏合适的了解雪豹情况 的关键信息人，因此没有进行威胁评估。

通过加权加和各省的威胁评分，可以得到全国 的威胁评分及排序。其中评分最高的三大威胁为: 基层保护能力不足(9.5分)、气候变化(8.0分)、当地 社区保护动力不足(6.8分)。如果按照威胁的类别来 看, 第一大类威胁一对雪豹的直接猎杀或抓捕中, 报复性猎杀评分最高(4.6分); 第二大类威胁——栖 息地和猎物相关威胁中, 家畜竞争导致的猎物种群 减少评分最高(6.1分); 第三大类威胁——政策与认 知相关威胁中, 基层保护部门能力不足排名第一 
表1 中国雪豹威胁列表

Table 1 Threat to snow leopard in China

\begin{tabular}{|c|c|c|c|}
\hline $\begin{array}{l}\text { 威胁分类 } \\
\text { Category of threat }\end{array}$ & $\begin{array}{l}\text { 威胁名称 } \\
\text { Threat }\end{array}$ & $\begin{array}{l}\text { 编号 } \\
\text { No. }\end{array}$ & $\begin{array}{l}\text { 参考文献 } \\
\text { Reference }\end{array}$ \\
\hline $\begin{array}{l}\text { 对雪豹的直接猎杀 } \\
\text { 或抓捕 }\end{array}$ & $\begin{array}{l}\text { 报复性猎杀 } \\
\text { In retribution for livestock depredation (RLD) }\end{array}$ & 1.1 & $\begin{array}{l}\text { Oli et al, 1994; Xu et al, 2008; Li et al, 2013; Alexander et al, 2015; } \\
\text { Chen et al, 2016; Wild Xinjiang }\end{array}$ \\
\hline \multirow{4}{*}{$\begin{array}{l}\text { Direct killing or } \\
\text { capture of snow } \\
\text { leopards }\end{array}$} & $\begin{array}{l}\text { 非法贸易导致的偷猎 } \\
\text { Poaching for illegal trade (PIT) }\end{array}$ & 1.2 & $\begin{array}{l}\text { Zhang, 1985; Schaller et al, 1988; Liu, 1993; EIA, 2008, 2012; } \\
\text { Peng, 2009; Ma, 2012; Li \& Lü, 2014; Maheshwari \& Niraj, } 2018\end{array}$ \\
\hline & $\begin{array}{l}\text { 动物园和博物馆的活体收集 } \\
\text { Zoo and museum collection of live animals } \\
\text { (ZMC) }\end{array}$ & 1.3 & Ma, 2012; Shan Shui Conservation Center \\
\hline & $\begin{array}{l}\text { 下毒、下套等导致的误杀 } \\
\text { Secondary poisoning and trapping (SPT) }\end{array}$ & 1.4 & Li et al, 2013; Shan Shui Conservation Center \\
\hline & 雪豹疾病 Diseases of snow leopards (DSL) & 1.5 & $\begin{array}{l}\text { Fix et al, 1989; Silinski et al, 2003; An, } 2016^{\oplus} \text {; Ostrowski \& } \\
\text { Gilbert, 2016; Shan Shui Conservation Center }\end{array}$ \\
\hline \multirow{5}{*}{$\begin{array}{l}\text { 栖息地和猎物相关 } \\
\text { 威胁 } \\
\text { Threat about habitats } \\
\text { and preys }\end{array}$} & 栖息地退化 Habitat degradation (HD) & 2.1 & Brown, 2008; Harris, 2010; Wang et al, 2015 \\
\hline & 栖息地破碎化 Habitat fragmentation (HF) & 2.2 & $\begin{array}{l}\text { World Wide Fund for Nature; Xu et al, 2008; Li, 2012; Wild } \\
\text { Xinjiang }\end{array}$ \\
\hline & $\begin{array}{l}\text { 盗猎和误杀导致的猎物种群减少 } \\
\text { Prey reduction due to poaching and mistaken } \\
\text { killing (PRPMK) }\end{array}$ & 2.3 & Schaller et al, 1988; Shan Shui Conservation Center \\
\hline & $\begin{array}{l}\text { 家畜竞争导致的猎物种群减少 } \\
\text { Prey reduction due to competition with livestock } \\
\text { (PRCL) }\end{array}$ & 2.4 & $\begin{array}{l}\text { Mishra et al, 2004; Suryawanshi et al, 2010; Xiao, 2017; Wild } \\
\text { Xinjiang }\end{array}$ \\
\hline & 猎物疾病 Diseases of prey (DP) & 2.5 & $\begin{array}{l}\text { Fedosenko \& Blank, 2001; Dagleish et al, 2007; Wang et al, 2009; } \\
\text { Bao et al, 2011; Ostrowski et al, 2011; Ostrowski \& Gilbert, 2016; } \\
\text { Wild Xinjiang }\end{array}$ \\
\hline \multirow{5}{*}{$\begin{array}{l}\text { 政策和认知相关 } \\
\text { 威胁 } \\
\text { Threat about policy } \\
\text { and cognition }\end{array}$} & $\begin{array}{l}\text { 普遍认知缺乏导致的政策不当 } \\
\text { Improper policy due to lack of cognition (IP) }\end{array}$ & 3.1 & Li et al, 2017 \\
\hline & $\begin{array}{l}\text { 政策实施不力 } \\
\text { Ineffective implementation of policies (IIP) }\end{array}$ & 3.2 & $\begin{array}{l}\text { Mishra et al, 2003; Chen et al, 2016; Shan Shui Conservation } \\
\text { Center }\end{array}$ \\
\hline & $\begin{array}{l}\text { 缺乏跨省(境)合作 } \\
\text { Lack of trans-boundary cooperation (LTC) }\end{array}$ & 3.3 & - \\
\hline & $\begin{array}{l}\text { 基层保护部门能力不足 } \\
\text { Insufficient capacity of local conservation } \\
\text { departments (ICLCD) }\end{array}$ & 3.4 & - \\
\hline & $\begin{array}{l}\text { 当地社区保护动力不足 } \\
\text { Lack of conservation incentive among local } \\
\text { communities (LCILC) }\end{array}$ & 3.5 & - \\
\hline \multirow[t]{6}{*}{$\begin{array}{l}\text { 间接威胁 } \\
\text { Indirect threat }\end{array}$} & 气候变化 Climate change (CC) & 4.1 & $\begin{array}{l}\text { IPCC, 2007; Klein et al, 2007; Xue et al, 2009; Vince, 2010; Yu et } \\
\text { al, 2010; Forrest et al, 2012; Lovari et al, 2013; Yao et al, 2013; Luo } \\
\text { et al, 2015; Aryal et al, 2016; Lehnert et al, 2016; Li et al, 2016; } \\
\text { Yang et al, } 2018\end{array}$ \\
\hline & $\begin{array}{l}\text { 人口增长和贫困 } \\
\text { Human population growth and poverty (HPGP) }\end{array}$ & 4.2 & $\begin{array}{l}\text { Mishra et al, 2001, 2003; Adams et al, 2004; McShane \& Wells, } \\
2004\end{array}$ \\
\hline & $\begin{array}{l}\text { 流浪狗袭击雪豹及其猎物 } \\
\text { Stray dogs attack snow leopards and their prey } \\
\text { (SDA) }\end{array}$ & 4.3 & $\begin{array}{l}\text { Wandeler et al, 1993; Butler et al, 2004; Mingyu Liu (Peking } \\
\text { University) }\end{array}$ \\
\hline & $\begin{array}{l}\text { 虫草/药草采挖造成的干扰 } \\
\text { Interference caused by cordyceps/herb collection } \\
\text { (ICCC) }\end{array}$ & 4.4 & Shan Shui Conservation Center \\
\hline & $\begin{array}{l}\text { 道路建设与旅游开发项目 } \\
\text { Road construction and tourism development } \\
\text { projects (RCTD) }\end{array}$ & 4.5 & Wild Xinjiang; Wolong National Nature Reserve \\
\hline & $\begin{array}{l}\text { 矿产与水电开发 } \\
\text { Mineral exploration and hydropower developmen } \\
\text { (MEHD) }\end{array}$ & 4.6 & Wingard \& Zahler, 2006; Baker et al, 2010; Jackson et al, 2013 \\
\hline
\end{tabular}



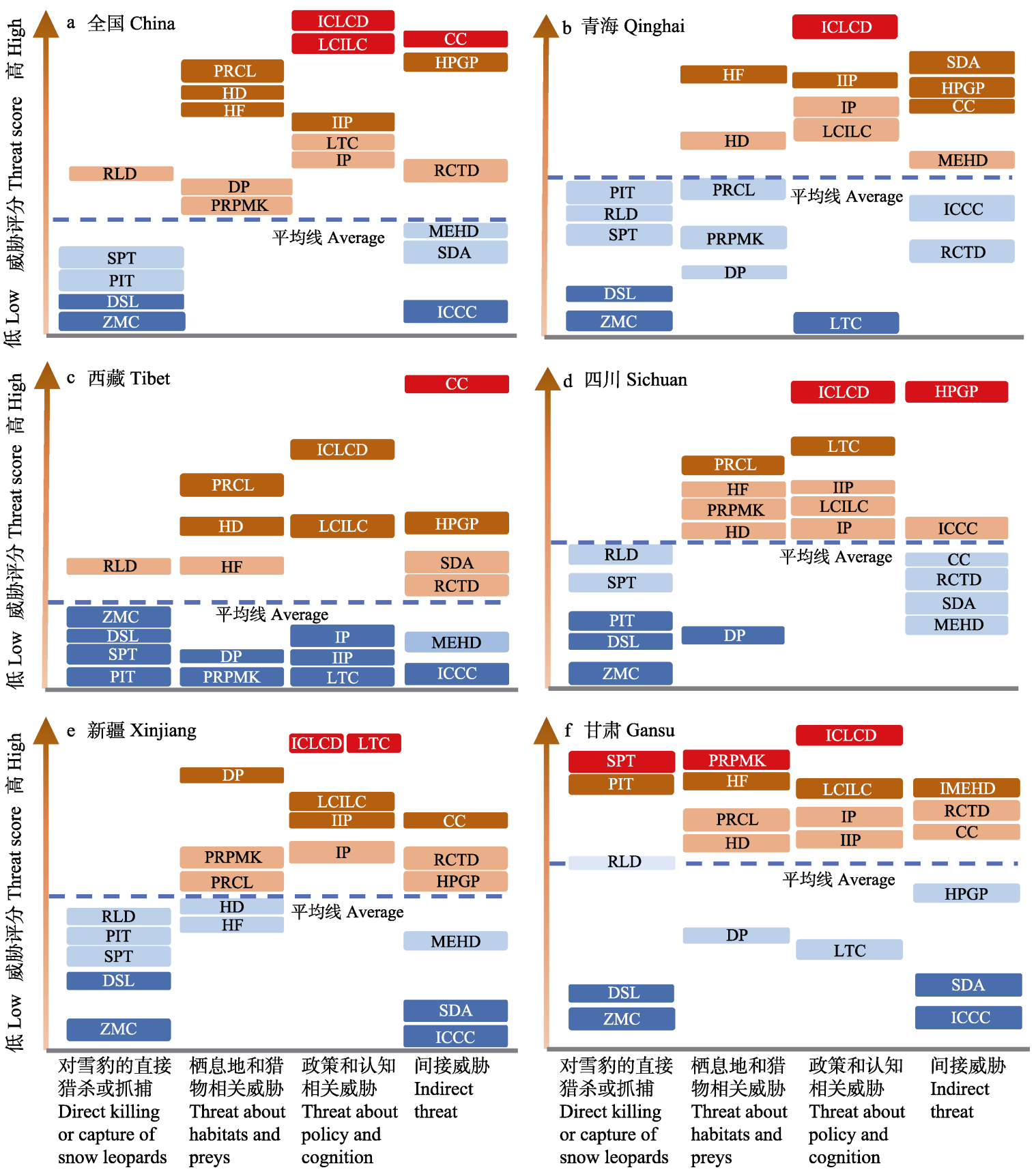

图1 全国及各省区雪豹所面临威胁的排序。RLD: 报复性猎杀; PIT: 非法贸易导致的偷猎; ZMC: 动物园和博物馆的活体 收集; SPT: 下毒、下套等导致的误杀; DSL：雪豹疾病; HD：栖息地退化; HF：栖息地破碎化; PRPMK：盗猎和误杀导致的 猎物种群减少; PRCL: 家畜竞争导致的猎物种群减少; DP: 猎物疾病; IP: 普遍认知缺乏导致的政策不当; IIP: 政策实施不 力; LTC: 缺乏跨省(境)合作; ICLCD: 基层保护部门能力不足; LCILC: 当地社区保护动力不足; CC: 气候变化; HPGP: 人 口增长和贫困; SDA: 流浪狗袭击雪豹及其猎物; ICCC: 虫草/药草采挖造成的干扰; RCTD: 道路建设与旅游开发项目; MEHD: 矿产与水电开发。

Fig. 1 Rankings of threats to snow leopard at national and provincial level. RLD, In retribution for livestock depredation; PIT, Poaching for illegal trade; ZMC, Zoo and museum collection of live animals; SPT, Secondary poisoning and trapping of snow leopards; DSL, Diseases of snow leopards; HD, Habitat degradation; HF, Habitat fragmentation; PRPMK, Prey reduction due to poaching and mistaken killing; PRCL, Prey reduction due to competition with livestock; DP, Diseases of prey; IP, Improper policy due to lack of cognition; IIP, Ineffective implementation of policies; LTC, Lack of trans-boundary cooperation; ICLCD, Insufficient capacity of local conservation departments; LCILC, Lack of conservation incentive among local communities; CC, Climate change; HPGP, Human population growth and poverty; SDA, Stray dogs attack snow leopards and their prey; ICCC, Interference caused by cordyceps/herb collection; RCTD, Road construction and tourism development projects; MEHD, Mineral exploration and hydropower development. 
(9.5分), 几乎所有评分者都会提及; 而第四大类威 胁一一间接威胁中, 气候变化评分最高(8.0)。

\section{3 威胁应对现状}

一共收集到18家雪豹研究与保护组织 $(n=16)$ 和各级政府部门/保护区 $(n=2)$ 共同推动的14项在 地保护行动, 以及国家层面惠及雪豹的3项政策, 最终汇总为17项保护行动, 可总结为三大类: 保护 地建设、在地保护行动、政策与公众推动。各项保 护行动的实施省区、应对威胁见表2。共收集到15 项保护行动的典型保护案例16个, 每个保护案例的 具体实施方和详细介绍见附录3。

\section{3 讨论}

\section{1 威胁排序对比与解读}

本文是我国第一次采用专家统一评分的方法 对雪豹所面临的威胁进行打分和评估，结果表明: (1)与China Snow Leopard Conservation Action Plan (Revised Manuscript) (China Forestry Administration, 2013)相比, 本次分析识别的威胁增加了报复性猎
杀、普遍认知缺乏导致的政策不当、政策实施不力、 缺乏跨省(境)合作、人口增长和贫困、流浪狗袭击 雪豹及其猎物、虫草/药草采挖造成的干扰7项。(2) 与2013年Snow Leopard Survival Strategy的评估结果 相似，在全国层面上，保护力量的缺乏依然是我国 雪豹保护面临的最主要问题，包括基层保护部门能 力不足和当地社区保护动力不足。缺乏跨省(境)合 作、家畜竞争导致的猎物种群减少、报复性猎杀、 道路建设与旅游开发项目、矿产与水电开发造成的影 响在本次威胁排序中的重要性有所降低。但本次分 析显示，气候变化已上升为不可忽视的重要威胁。

除共有的基层保护能力不足外，各省区面临的 主要威胁各有特色。青海省由于藏獒市场的崩溃, 流浪狗袭击雪豹及其猎物的威胁列第二位; 西藏自 治区由于冰川、冻土融化的影响显著，气候变化是 最严重的威胁; 四川省市场化程度最高, 经济发展 与环境保护的矛盾也最大, 因此人口增长与贫困排 第一位; 新疆地处边疆, 与八国接壤, 而阿尔泰山、 天山西部和南部、准噶尔界山、帕米尔高原都是与

表2 全国及各省区开展的保护行动及其应对的威胁(编号含义见表1)

Table 2 Protective actions and corresponding threat at national and provincial level (Mean of the numbers are shown in Table 1)

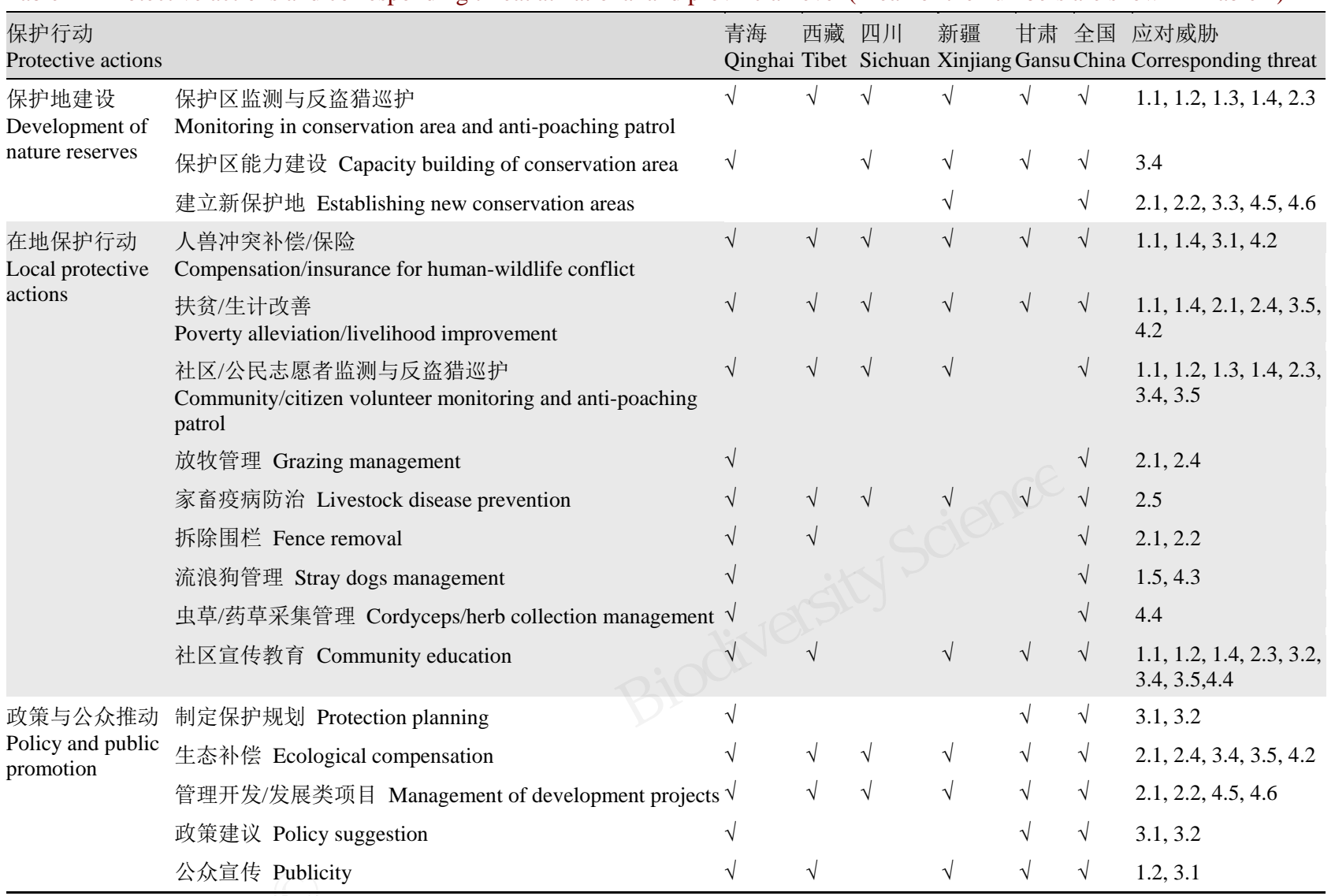


邻国相连的完整雪豹栖息地, 但边境隔离设施对跨 境雪豹种群造成了分割, 因此缺乏跨省(境)合作在 威胁中排第二位; 甘肃省的临夏历史上曾是野生动 物皮毛交易中心，现在市场虽然已经关闭，但该省 的盗猎水平依然整体较高, 对雪豹猎物的猎杀和下 毒、下套等导致的误杀分别排在第二和第三位。

\section{2 保护现状评估}

\subsection{1 全国层面}

基于图1和表2的结果, 在全国层面, 我们着重 关注了排在前三位的威胁和尚无任何保护行动应 对的威胁。实际上，尚无任何行动应对的威胁只有 气候变化这一项, 而气候变化也正好排在前三位。 对这三项威胁的具体分析如下:

(1)基层保护部门能力不足。图2展示了我国保 护区和全球20个重要雪豹景观所覆盖的雪豹栖息 地范围。保护区能力不足的问题表现在以下几个方 面: (a)我国保护区覆盖的雪豹栖息地面积 $\left(40\right.$ 万 $\left.\mathrm{km}^{2}\right)$ 仅占全国雪豹栖息地面积(178万 $\mathrm{km}^{2}, \mathrm{Li}$ et al, 投稿 中)的 $22 \%$, 保护区外的广大雪豹栖息地得不到有效 保护; (b)已有的保护区由于资金、人力或能力的不 足, 能够独立开展雪豹调查和监测的屈指可数; (c) 有雪豹分布的保护区，没有一个制定了相应的雪豹 保护规划, 也没有明确的保护目标; (d)全球雪豹及
其生态系统保护项目(Global Snow Leopard \& Ecosystem Protection Program, GSLEP)计划通过各国政 府间合作，在2020年前优先保护 20 个全球重要雪豹 景观，这本可以作为原有保护地体系的重要补充， 在此基础上建立保护小区或国家公园，并制定相应 的保护规划，但由于我国官方和民间信息分享不足， 仅有塔什库尔干、托木尔峰和盐池湾 3 个地区入选。

如今, 应对基层保护部门能力不足的行动主要 是保护区能力建设和社区监测与巡护/公民志愿者 监测与巡护。但这两个行动的力度都不够大, 覆盖 面积有限，依然有大量保护区内外的雪豹栖息地得 不到有效的监测和保护。

(2)气候变化。目前尚无任何专项保护行动应对 气候变化, 需要引起足够的重视。

(3)当地社区保护动力不足。目前，中国的雪豹 分布区内, 绝大多数基层群众知道雪豹是一级保护 动物，知道杀死雪豹是违法的，也普遍具有朴素的 生态观念。但长期以来, 在生计压力和现行保护管 理体制下，群众没有机会深度参与家乡的保护工作, 对野生动物持负面态度, 来自基层内部的保护力量 极其缺乏。在监管和补偿措施不到位的情况下，负 面态度有可能快速转化为报复性猎杀或其他破坏 自然栖息地的行为，对雪豹保护造成威胁。但社区

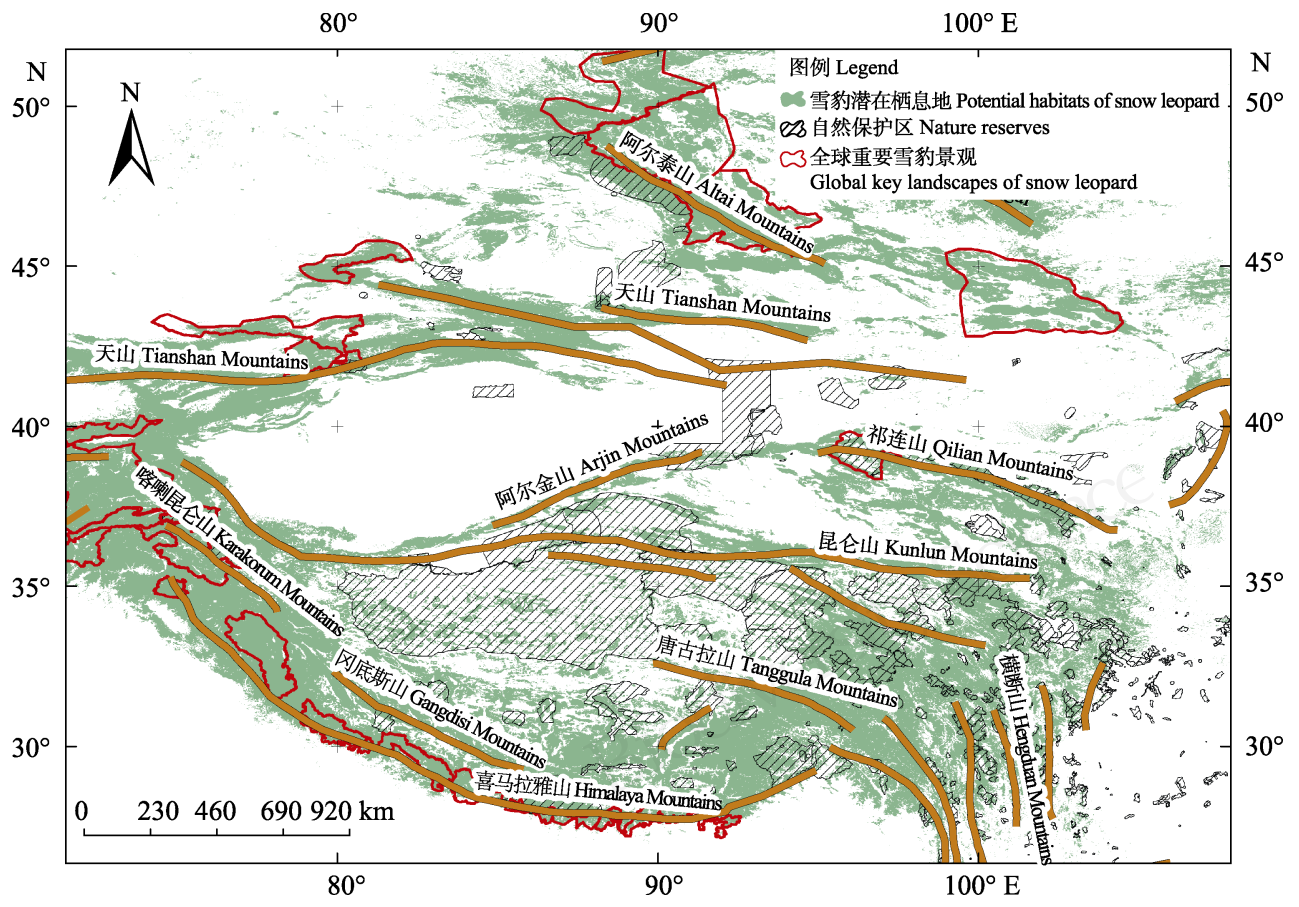

图2 全球重点雪豹景观、全国保护区和雪豹分布位置关系图

Fig. 2 Global key landscape of snow leopard, national protected area and snow leopard distribution map 
更有希望成为雪豹保护的巨大助力。因此, 增强社 区对雪豹的保护动力是雪豹保护中最重要的任务之 一。虽然社区宣传、社区监测与巡护、扶贫/生计改 善等在各地都有尝试, 但相比雪豹栖息地来说范围 仍然太小，需要民间和政府合力扩大行动范围。虽然 西部地区大面积实施了生态补偿的国家政策，但该 政策主要针对草地和森林而非野生动物, 尚需要出 台与野生动物保护成效直接挂钩的生态补偿政策。

\subsection{2 省区层面}

青海省为应对流浪狗的威胁建立了流浪狗收 容所, 试点了绝育和兽医培训项目, 但都是小范围 的尝试; 西藏自治区尚未开展针对气候变化的任何 保护行动; 四川省近年来开展的精准扶贫项目覆盖 面积广, 对人口增长和贫困的缓解应该有很大帮助, 但仍有部分地区人口密度较大，社区居民保护意识 相对较差, 盗猎现象较难根治; 新疆维吾尔自治区 因边境隔离设施而对雪豹栖息地的分割问题较难 解决; 甘肃省为应对盗猎导致的猎物种群减少和对 雪豹误杀的威胁, 在保护区开展了监测与反盗猎巡 护, 但仍需加强巡护和执法力度。

\section{3 保护建议}

为应对基层保护部门能力不足的问题, 需要在 保护地以建设巡护监测管理体系为抓手, 加大管护 力度, 优化管理模式, 这对中国雪豹保护具有重要 意义。在我国, 部分保护地拥有健康的雪豹种群, 这些重点保护地包括祁连山国家公园、三江源国家 公园、西藏㒸塘国家级自然保护区、西藏色林错国 家级自然保护区、西藏珠穆朗玛峰国家级自然保护 区、新疆托木尔峰国家级自然保护区、四川卧龙国 家级自然保护区、四川贡嘎山国家级自然保护区 等。因此, 首先在这些重点保护地建立起监测巡护 管理系统, 应是我国雪豹保护工作在接下来5年内 的重点之一。建议: (1)采用网格化的管理方式, 分 解管护任务, 落实责任主体, 实施量化考核, 实现 巡护和监测的标准化; (2)开展综合能力建设系列培 训，针对不同管理层级设定培训内容。

在提高社区保护动力方面, 建设社区保护示范 地是有效对策。我们建议在西藏、新疆、青海、甘 肃和四川等雪豹分布重点省区, 至少建成5个社区 综合保护示范地。在示范地内, (1)建立人兽冲突缓 解机制, 试点事前防御措施和事后补偿方案; (2)设 立保护激励资金, 外部激励与当地保护成效直接挂
钩; (3)设立专项基金, 探索绿色生计模式; (4)总结 并推广示范经验, 为其他雪豹分布区社区和政府提 供有益借鉴。

针对气候变化的威胁, 其他雪豹分布国开展过 的行动主要是适应性生计项目, 并尽可能不使气候 变化导致的栖息地退化问题进一步恶化。我国可以 借鉴别国经验，尽早展开应对。

此外, 虽然我国已积累了不少雪豹保护经验, 但综合保护方案仍停留在试点阶段。我们建议在未 来5年内, 在雪豹调查和监测、保护地能力建设和社 区保护示范的基础上，西藏、新疆、青海、甘肃、 四川等雪豹重点分布省区应形成省/自治区级的全 局性保护规划和行动方案。同时, 要加强“中国雪豹 保护网络”的建设，使之成为政府与民间、国内与国 外，以及民间机构之间的沟通合作平台，设立中国 雪豹保护联席会议, 建立专家组, 吸纳国内外高 校、科研院所、保护与社区发展组织、环保类基金 会、媒体、企业等积极参与中国雪豹保护事业, 加 强向群众的宣传。

\section{4 本研究的意义与不足}

本研究所使用的评估威胁的方法, 由于其评分 标准的统一性, 未来在重评估各省区的雪豹保护情 况时具有很好的实用性。基于本研究得出的威胁排 序和保护现状评估, 参考已有的保护行动范例, 各 省区可以有针对性地实施保护行动, 配置保护资源, 力争保护目标更快更优地实现。但必须承认：(1)由 于威胁评分是省区内的纵向对比, 反映的是各威胁 因素在各省区内的相对严重程度, 所以将各省评分 进行横向对比的意义不大; (2)评分过程中依然存在 对排序依据的解读不一致的问题, 可能对打分的准 确程度有所影响; (3)此次威胁评级中的第三大类 一政策与认知相关威胁, 更准确的称呼可能是限 制保护的短板, 而非真正的威胁, 在未来的威胁评 级和保护状况评估中, 应对此类短板单独排序和分 析; (4)由于短期内难以定量评估各项保护行动的覆 盖面积和保护成效, 尚未做到对保护现状评估的定 量分析。希望全国相关机构和个人精诚合作, 更加 准确全面地评估威胁、分析保护现状、分享保护经 验, 为中国的雪豹保护工作共同努力。

致谢: 本次威胁评级工作和保护现状分析的完成, 
得益于过去多年来众多组织、机构与个人在雪豹研 究和保护议题上卓有成效的行动, 而这些行动的背 后，是众多关注雪豹研究和保护的政府、基金会以 及企业长期持续的支持, 在此对他们表示感谢。感 谢国家林业和草原局及各主管部门对雪豹保护的 投入和支持，这是中国雪豹得到有效保护的重要基 础。感谢北京林业大学时坤教授对分析结果提出的 宝贵意见。

\section{参考文献}

Adams WM, Aveling R, Brockington D, Dickson B, Elliott J, Hutton J, Roe D, Vira B, Wolmer W (2004) Biodiversity conservation and the eradication of poverty. Science, 306, 1146-1149.

Aipanjiguly S, Jacobson SK, Flamm R (2003) Conserving manatees: Knowledge, attitudes, and intentions of boaters in Tampa Bay, Florida. Conservation Biology, 17, 1098-1105.

Alexander J, Chen P, Damerell P, Youkui W, Hughes J, Shi K, Riordan P (2015) Human wildlife conflict involving large carnivores in Qilianshan, China and the minimal paw-print of snow leopards. Biological Conservation, 187, 1-9.

Aryal A, Shrestha UB, Ji W, Ale SB, Shrestha S, Ingty T, Maraseni T, Cockfield G, Raubenheimer D (2016) Predicting the distributions of predator (snow leopard) and prey (blue sheep) under climate change in the Himalaya. Ecology and Evolution, 6, 4065-4075.

Baker MS, Elias N, Guzmán E, Soto-Viruet Y (2010) Mineral facilities of Asia and the Pacific. http://pubs.usgs.gov/of/ 2010/1254/. (accessed on 2012-11-09)

Bao J, Wang Z, Li L, Wu X, Sang P, Wu G, Ding G, Suo L, Liu C, Wang J, Zhao W, Li J, Qi L (2011) Detection and genetic characterization of peste des petits ruminants virus in free-living bharals (Pseudois nayaur) in Tibet, China. Research in Veterinary Science, 90, 238-240.

Brown LR (2008) Plan B 3.0: Mobilizing to Save Civilization (substantially revised). WW Norton \& Company, New York.

Butler JRA, Du Toit JT, Bingham J (2004) Free-ranging domestic dogs (Canis familiaris) as predators and prey in rural Zimbabwe: Threats of competition and disease to large wild carnivores. Biological Conservation, 115, 369-378.

Chen P, Gao Y, Lee AT, Cering LL, Shi K, Clark SG (2016) Human-carnivore coexistence in Qomolangma (Mt. Everest) Nature Reserve, China: Patterns and compensation. Biological Conservation, 197, 18-26.

China Forestry Administration (2013) China Snow Leopard Conservation Action Plan (Revised Manuscript). http://www. globalsnowleopard.org/wp-content/uploads/2016/05/China_ NSLEP.pdf. (accessed on 2019-01-28)

Dagleish MP, Qurban A, Powell RK, Butz D, Woodford MH
(2007) Fatal Sarcoptes scabiei infection of blue sheep (Pseudois nayaur) in Pakistan. Journal of Wildlife Diseases, 43, 512-517.

Donlan CJ, Wingfield DK, Crowder LB, Wilcox C (2010) Using expert opinion surveys to rank threats to endangered species: A case study with sea turtles. Conservation Biology, 24, 1586-1595.

EIA (2008) Skin Deep: The need for effective enforcement to combat the Asian big cat skin trade. In: The 57th Meeting of the CITES Standing Committee FIC Europe, Brussels.

EIA (2012) Briefing on snow leopards in illegal trade-Asia's forgotten cats. In: The 2nd Asian Ministerial Conference on Tiger Conservation, Bhutan.

Fedosenko AK, Blank DA (2001) Capra sibirica. Mammal Species, 675, 1-13.

Fix AS, Riordan DP, Hill HT, Gill MA, Evans EB (1989) Feline panleukopenia virus and subsequent canine distemper virus infection in two snow leopards (Panthera uncia). Journal of Zoo and Wildlife Medicine, 20, 273-281.

Forrest JL, Wikramanayake E, Shrestha R, Areendran G, Gyeltshen K, Maheshwari A, Mazumdar S, Naidoo R, Thapa GJ, Thapa K (2012) Conservation and climate change: Assessing the vulnerability of snow leopard habitat to treeline shift in the Himalaya. Biological Conservation, 150, 129-135.

Harris RB (2010) Rangeland degradation on the QinghaiTibetan Plateau: A review of the evidence of its magnitude and causes. Journal of Arid Environments, 74, 1-12.

Intergovernmental Panel on Climate Change (IPCC) (2007) Climate Change 2007: Synthesis Report. https://www.ipcc. ch/site/assets/uploads/2018/02/ar4_syr_full_report.pdf. (accessed on 2019-01-28)

Jackson RM, Mallon D, Sharma RK, Suryawanshi KS, Mishra C (2013) Snow Leopard Survival Strategy. Version 2013.1, Snow Leopard Network, Seattle.

Kerr RA (1996) A new way to ask the experts-Rating radioactive waste risks. Science, 274, 913-914.

Klein JA, Harte J, Zhao X (2007) Experimental warming, not grazing, decreases rangeland quality on the Tibetan Plateau. Ecological Applications, 17, 541-557.

Lehnert LW, Wesche K, Trachte K, Reudenbach C, Bendix J (2016) Climate variability rather than overstocking causes recent large-scale cover changes of Tibetan pastures. Scientific Reports, 6, 24367.

Li J (2012) Ecology and Conservation Strategy of Snow Leopard (Panthera uncia) in Sanjiangyuan Area on the Tibetan Plateau. PhD dissertation, Peking University, Beijing. (in Chinese with English abstract) [李娟 (2012) 青藏 高原三江源地区雪豹(Panthera uncia)的生态学研究及保 护. 博士学位论文, 北京大学, 北京.]

Li J, Lü Z (2014) Snow leopard poaching and trade in China 2000-2013. Biological Conservation, 176, 207-211.

Li J, McCarthy TM, Wang H, Weckworth BV, Schaller GB, 
Mishra C, Lü Z, Beissinger SR (2016) Climate refugia of snow leopards in High Asia. Biological Conservation, 203, 188-196.

Li J, Yin H, Wang D, Jiagong Z, Lü Z (2013) Human-snow leopard conflicts in the Sanjiangyuan Region of the Tibetan Plateau. Biological Conservation, 166, 118-123.

Li L, Fassnacht FE, Storch I, Bürgi M (2017) Land-use regime shift triggered the recent degradation of alpine pastures in Nyanpo Yutse of the eastern Qinghai-Tibetan Plateau. Landscape Ecology, 8, 1-17.

Liu WL (1993) Brief history about conservation and utilization of wild animals on the Tibetan Plateau. Journal of Tibet University, 8(1), 45-49. (in Chinese) [刘务林 (1993) 西藏 高原人类保护利用野生动物简史. 西藏大学学报, 8(1), 45-49.]

Lovari S, Ventimiglia M, Minder I (2013) Food habits of two leopard species, competition, climate change and upper treeline: A way to the decrease of an endangered species. Ethology Ecology \& Evolution, 25, 305-318.

Luo Z, Jiang Z, Tang S (2015) Impacts of climate change on distributions and diversity of ungulates on the Tibetan Plateau. Ecological Applications, 25, 24-38.

Ma KP, Qian YQ (1998) Biodiversity conservation and its research progress. Chinese Journal of Applied and Environmental Biology, 4, 95-99. (in Chinese with English abstract) [马克平, 钱迎倩 (1998) 生物多样性保护及其 研究进展. 应用与环境生物学报, 4, 95-99.]

Ma M (2012) Market prices for the tissues and organs of snow leopards in China. Selevinia, 516, 119-122.

Maheshwari A, Niraj SK (2018) Monitoring illegal trade in snow leopards: 2003-2014. Global Ecology and Conservation, 14 , e00387.

Martin TG, Kuhnert PM, Mengersen K, Possingham HP (2005) The power of expert opinion in ecological models using Bayesian methods: Impact of grazing on birds. Ecological Applications, 15, 266-280.

McCarthy T, Mallon D, Jackson R, Zahler P, McCarthy K (2017) Panthera uncia. The IUCN Red List of Threatened Species 2017. http://dx.doi.org/10.2305/IUCN.UK.2017-2. RLTS.T22732A50664030.en. (accessed on 2019-01-11)

McShane TO, Wells MP (2004) Getting Biodiversity Projects to Work: Towards More Effective Conservation and Development. Columbia University Press, New York.

Mishra C, Allen P, McCarthy T, Madhusudan MD, Bayarjargal A, Prins HHT (2003) The role of incentive programs in conserving the snow leopard. Conservation Biology, 17, 15121520.

Mishra C, Prins HHT, Wieren VSE (2001) Overstocking in the Trans-Himalayan rangelands of India. Environmental Conservation, 28, 279-283.

Mishra C, Wieren SEV, Ketner P, Heitkonig IMA, Prins HHT (2004) Competition between domestic livestock and wild bharal Pseudois nayaur in the Indian Trans-Himalaya.
Journal of Applied Ecology, 41, 344-354.

Oli MK, Taylor IR, Rogers ME (1994) Snow leopard (Panthera uncia) predation of livestock: An assessment of local perceptions in the Annapurna Conservation Area, Nepal. Biological Conservation, 68, 63-68.

Ostrowski S, Gilbert M (2016) Diseases of free-ranging snow leopards and primary prey species. In: Snow Leopard (eds McCarthy T, Mallon D), pp. 97-112. Academic Press, London.

Ostrowski S, Thiaucourt F, Amirbekov M, Mahmadshoev A, Manso-Silván L, Dupuy V, Vahobov D, Ziyoev O, Michel S (2011) Fatal outbreak of Mycoplasma capricolum pneumonia in endangered markhors. Emerging Infectious Disease, 17, 2338-2341.

Peng JT (2009) An investigation on snow leopard resources in Ganzi Prefecture in the Hengduan Mountains on the southeast of the Qinghai-Tibet Plateau. Journal of Sichuan Forestry Science and Technology, 30(1), 57-58, 47. (in Chinese with English abstract) [彭基泰 (2009) 青藏高原 东南横断山脉甘孜地区雪豹资源调查研究. 四川林业科 技, 30(1), 57-58, 47.]

Salafsky N, Margoluis R (1999) Threat reduction assessment: A practical and cost-effective approach to evaluating conservation and development projects. Conservation Biology, 13, 830-841.

Schaller GB, Junrang R, Mingjiang Q (1988) Status of the snow leopard (Panthera uncia) in Qinghai and Gansu provinces, China. Biological Conservation, 45, 179-194.

Silinski S, Robert N, Walzer C (2003) Canine distemper and toxoplasmosis in a captive snow leopard (Uncia uncia)-A diagnostic dilemma. Verhandlungsbericht des Symposium uber die Erkrankungen der Zootiere, 41, 107-111.

Suryawanshi KR, Bhatnagar YV, Mishra C (2010) Why should a grazer browse? Livestock impact on winter resource use by bharal Pseudois nayaur. Oecologia, 162, 453-462.

Vince G (2010) A himalaya village builds artificial glaciers to survive global warming. https://www.scientificamerican.com/ article/artificial-glaciers-to-survive-global-warming/. (accessed on 2012-09-11)

Wandeler A, Matter H, Kappeler A, Budde A (1993) The ecology of dogs and canine rabies: A selective review. Revue Scientifique et Technique (International Office of Epizootics), 12(1), 51-71.

Wang Z, Bao J, Wu X, Liu Y, Li L, Liu C, Suo L, Xie Z, Zhao W, Zhang W, Yang N, Li J, Wang S, Wang J (2009) Peste des petits ruminants virus in Tibet, China. Emerging Infectious Disease, 15, 299-301.

Wang P, Lassoie JP, Morreale SJ, Dong S (2015) A critical review of socioeconomic and natural factors in ecological degradation on the Qinghai-Tibetan Plateau, China. The Rangeland Journal, 37, 1-9.

Wingard JR, Zahler P (2006) Silent Steppe: The Illegal Wildlife Trade Crisis in Mongolia. The World Bank, Washington, 
DC.

Xiao LY (2017) The Interaction Among Snow Leopards (Panthera uncia), Blue Sheep (Pseudois nayaur) and Livestock in Sanjiangyuan Region. PhD dissertation, Peking University, Beijing. (in Chinese with English abstract) [肖凌云 (2017) 三江源地区雪豹(Panthera uncia)、岩羊(Pseudois nayaur)与家畜的竞争与捕食关系研究. 博士学位论文, 北京大学, 北京.]

Xu A, Jiang Z, Li C, Guo J, Da S, Cui Q, Yu S, Wu G (2008) Status and conservation of the snow leopard Panthera uncia in the Gouli Region, Kunlun Mountains, China. Oryx, 42, 460-463.

Xue X, Guo J, Han B, Sun Q, Liu L (2009) The effect of climate warming and permafrost thaw on desertification in the Qinghai-Tibetan Plateau. Geomorphology, 108, 182-190.

Yang Y, Hopping K, Wang G, Chen J, Peng A, Klein JA (2018) Permafrost and drought regulate vulnerability of Tib- etan Plateau grasslands to warming. Ecosphere, 9, e02233.

Yao T, Wang Y, Liu S, Pu J, Shen Y, Lu A (2013) Recent glacial retreat in High Asia in China and its impact on water resource in Northwest China. Science in China, 47, 10651075.

Yu H, Luedeling E, Xu J (2010) Winter and spring warming result in delayed spring phenology on the Tibetan Plateau. Proceedings of the National Academy of Sciences, USA, 107, 22151-22156.

Zhang DM (1985) The dynamics of a few animals during the last thirty years in Ili Prefecture, Xinjiang Uygur Autonomous Region. Acta Theriologica Sinica, 5, 56, 66. (in Chinese) [张大铭 (1985) 新疆伊犁地区近三十年来几种 兽类的动态. 兽类学报, 5, 56, 66.]

(责任编委: 蒋志刚 责任编辑: 黄祥忠)

\section{附录 Supplementary Material}

附录1 雪豹所面临的威胁因素详情

Appendix 1 Details of threats to snow leopard

http://www.biodiversity-science.net/fileup/PDF/2019026-1.pdf

\section{附录2 全国及各省区雪豹面临威胁的评分}

Appendix 2 Score of threats to snow leopard at national and provincial level http://www.biodiversity-science.net/fileup/PDF/2019026-2.xlsx

\section{附录3 国内已有的雪豹保护行动案例}

Appendix 3 Existing snow leopard protective actions in China http://www.biodiversity-science.net/fileup/PDF/2019026-3.pdf 
李小雨, 肖凌云, 梁旭永, 程琛, 冯琛, 赵翔, 刘炎林, 市晓星, 何兵, 张常智, Justine Shanti Alexander, 邢睿, 黄亚慧, 阿旺久美, 谢然尼玛, 宋大昭, 黄巧雯, 扎西桑俄, 彭奎, 尹杭, 连新明, 杨欣, 李易, 施小刚, 杨创 明, 吕植. 中国雪豹的威胁与保护现状. 生物多样性, 2019, 27 (9): 932-942.

http://www.biodiversity-science.net/CN/10.17520/biods.2019026

附录1 雪豹所面临的威胁因素详情

Appendix 1 Details of threats to snow leopard

\section{A. 对雪豹的直接猎杀或抓捕}

(1)报复性猎杀

雪豹及同域分布的捕食者时常猎杀家畜, 造成较大损失。这可能导致当地群众怨恨雪豹、狼等大型食 肉动物, 降低群众的容忍度, 从而认为只有消灭食肉动物才是解决冲突的唯一措施(Oli et al, 1994)。在中国, 雪豹造成的家畜损失似乎低于其他雪豹分布国(Xu et al, 2008; Li et al, 2013; Alexander et al, 2015; Chen et al, 2016)。 $\mathrm{Li}$ 等(2013)发现，在青海省三江源，只有 $10 \%$ 的家畜损失与雪豹有关，而 $45 \%$ 与狼有关, $42 \%$ 与疾病 相关。Li 等(2013)、Chen 等(2016)、Alexander 等(2015)和 Xu 等(2008)发现，在青海省三江源地区、青海昆 仑山、甘肃祁连山和西藏珠峰地区, 当地牧民对雪豹的容忍度较高, 但对造成更大量家畜损失的其他食肉动 物(如狼)的容忍度较低。在新疆天山东部区域, 2016 年北山羊种群感染小反刍兽疫大量死亡, 造成野生猎物 缺乏, 当地雪豹种群对家畜的捕食强度陡然增加。牧民对新近出现的雪豹捕食家畜事件难以适应，表现出较 低的容忍度(荒野新疆)。

\section{（2)非法贸易导致的偷猎}

雪豹因其毛皮和肉而遭到猎杀，并被买卖。所有分布国均已立法保护雪豹，并且从 1975 年起雪豹就被 列入 CITES 附录 1 。然而, 各分布国的非法贸易仍然是雪豹的持续威胁。环境调查协会(Environmental Investigation Agency, EIA)总结了自 2005 年起亚洲非法野生动物贸易的研究结果。2000 年以来, 12 个雪豹分 布国共缴获了 151 张雪豹皮。据估计, 海关查出的案件只占实际数量的 $10 \%$ 左右。所以, 过去 12 年间, 可 能有多达 1,000 起雪豹个体非法交易, 占全球雪豹种群的 1/6 左右(EIA, 2012)。最新研究显示, 2003-2014 年 间, 除哈萨克斯坦以外的 11 个雪豹分布国共发现 88 起非法交易, 涉及 439 只雪豹, 占全球雪豹种群的 8.4\%-10.9\%, 我国占其中的 50\% (222 只), 阿富汗占 30\% (132 只)。尽管各国野生动物执法和犯罪控制力度 显著加强, 但与 1993-2002 年相比, 2003-2012 年间雪豹贸易依然增长了 61\% (Maheshwari \& Niraj, 2018)。 $\mathrm{Li}$ 和 $\mathrm{Lu}$ (2014)收集了中国 2000-2013 年的雪豹猎杀案例, 共有 43 起, 牵涉至少 98 只雪豹。早期雪豹制品 交易主要集中于省内城市。从 2010 年开始, 市场开始向中国更加富裕的沿海城市扩张, 贸易也向奢侈品方 向转变。

根据刘务林(1993)的估计, 20 世纪 80 年代以前, 西藏每年猎杀 200-300 只雪豹。政府的皮毛收缴记录 显示, 1968-1971 年间, 仅在西藏昌都就有 88 只雪豹遭到猎杀(Schaller et al, 1988)。20 世纪 90 年代, 政府为 了控制食肉动物数量, 雪豹继续遭到捕杀。Peng (2009)发现, 20 世纪 60-80 年代, 四川省政府每年从本地猎 人手里收购 20-30 张雪豹皮毛。根据张大铭(1985), 仅在新疆伊犁哈萨克自治州, 1955-1965 年间, 雪豹皮张 贸易数量就达到平均每年 30 张, 且 1965 年一年就高达 135 张。 $\mathrm{Li}$ 和 $\mathrm{Lu}(2014)$ 通过半结构化访谈发现, 三 江源地区每年约有 11 只雪豹被杀，占当地雪豹种群的 1.2\%。Ma (2012)的问卷调查显示, 1960-2010 年间偷 猎贸易增加。新疆雪豹研究小组(XSLT)通过暗访和问卷调查, 收集到新疆 2002-2012 年间 387 起雪豹及其 制品的市场交易与盗猎信息(Ma, 2012)。甘肃省临夏曾是动物皮毛的交易中心，曾聚集 8 万人之众。交易者 声称所售卖的亚洲大型猫科动物皮毛来自阿富汗、缅甸、中国、印度、蒙古、巴基斯坦、俄罗斯和越南(EIA, 2008)。

\section{(3)动物园和博物馆的活体收集}

在新疆的 387 起雪豹及其制品的市场交易与盗猎事件中，排名前四的分别是：野外自然观察时碰到的 盗猎 $(17 \%)$, 为动物园收集动物进行的捕获 $(16 \%)$, 个人毛皮收集(13\%)和中药应用 $(9 \%)(\mathrm{Ma}, 2012)$ 。当地群众 遇到误闯人类领地、生病的或者落单的雪豹时, 往往不知如何处理, 可能会通过林业系统联系动物园。这种 处理方式可能使这些雪豹丧失了潜在的野外放归的机会。博物馆的标本收集也可能帮助当地人转卖掉手中 的雪豹尸体，无意中刺激报复性猎杀和盗猎(山水自然保护中心)。

\section{(4)下毒、下套等导致的误杀}

针对其他野生动物下毒或设置陷阱同样可能误杀雪豹。比如，青海省通天河沿岸用来抓捕马㭩的陷阱 就对雪豹产生了严重的威胁。2014 年冬季, 当地村民在一个山谷中找到数百个设置在柏树林中的铁丝脖套, 
李小雨, 肖凌云, 梁旭永, 程琛, 冯琛, 赵翔, 刘炎林, 市晓星, 何兵, 张常智, Justine Shanti Alexander, 邢睿, 黄亚慧, 阿旺久美, 谢然尼玛, 宋大昭, 黄巧雯, 扎西桑俄, 彭奎, 尹杭, 连新明, 杨欣, 李易, 施小刚, 杨创 明, 吕植. 中国雪豹的威胁与保护现状. 生物多样性, 2019, 27 (9): 932-942.

http://www.biodiversity-science.net/CN/10.17520/biods.2019026

雪豹和其他动物很难避开(山水自然保护中心)。一些当地人捕杀狼的毒药和陷阱也会杀死雪豹 (Li et al, 2013)。 在四川西部, 有很多针对林榒或白唇鹿的猎套, 尤其是雅江县的猎套密度高得惊人(山水自然保护中心)。另 外, 一些当地居民在开辟、维持高山牧场时, 往往会对非特定的大型食肉动物下毒“清场”, 对雪豹造成很大 威胁。

\section{(5)雪豹疾病}

极少有记录表明野生雪豹死亡是由于疾病引起的, 因此很难评估这项威胁的严重程度。2000-2008 年, 侯赛恩·阿里(Hussain Ali)在巴基斯坦北部的红其拉甫地区检查了 14 具雪豹尸体, 并没发现明显死于疾病的 案例。但与盗猎类似, 传染病导致的死亡很容易被低估。雪豹栖息地太过险峻, 研究人员很难发现或调查死 亡事件。传染病可能是雪豹种群的固有特征, 但随着压力增加和家养食肉动物的蔓延, 传染病的影响增大, 特别是当雪豹种群下降时 (Ostrowski \& Gilbert, 2016)。犬瘟病毒对野生豹亚科动物影响极大。圈养雪豹中出 现过两例, 都是与其他病原体同时感染(Fix et al, 1989; Silinski et al, 2003)。炭疽由炭疽杆菌引起, 曾在非洲 造成野生猫科动物的死亡, 大部分雪豹分布区报道过这种疾病。2011 年 4 月, 一只带有监测颈圈的雪豹死 在蒙古的戈壁沙漠。虽然研究人员没有对这只雪豹进行确定性的病理学检测, 而且炭疽在蒙古的这一区域 也不流行, 不过可以从症状推测死因为炭疽: 死亡雪豹的颈部有明显水肿, 鼻腔有未凝结的带血分泌物( $\mathrm{K}$. Smimaul personal communication)。

中国农业大学的安妮 $(2016)^{\circledR}$ 从青海省三江源地区收集了 29 份野生雪豹粪便样本, 寄生虫检出率为 $89.66 \%$ 。寄生虫种类包括猫等狍球虫、毛滴虫、猫弓首蛔虫、狮弓蛔虫、钩虫、棘球绦虫或带绦虫、丝状 网尾线虫、分体吸虫、前后盘吸虫。2016-2017 年, 青海三江源地区救助的两只雪豹活体和牧民报告的三具 雪豹尸体, 经兽医检验都不是由传染性疾病导致(山水自然保护中心)。2014 年, 《我们诞生在中国》的雪豹 拍摄组在三江源的拍摄地发现过一只半岁大的小雪豹在抽搐癫㾋之后迅速死亡, 可能是中毒或疾病导致, 兽医没有给出统一结论。

\section{B. 栖息地和猎物相关威胁}

\section{(1)栖息地退化}

雪豹栖息地与畜牧业分布区高度重叠，而目前全球草场的状况不容乐观，将近一半轻度到中度退化，5\% 重度退化(Brown, 2008)。因为不合理利用和气候变化等因素, 中国雪豹分布区也面临着草地沙漠化和草场 退化的威胁(Harris, 2010; Wang et al, 2015)。这直接影响到雪豹的野生猎物种群, 从而限制雪豹种群的健康 发展。

\section{(2)栖息地破碎化}

在部分雪豹分布区，地形本身就会导致栖息地的破碎化，比如川西、疆北等被人类聚居地包围的孤立 山峰。但围栏和道路等线性障碍会加剧破碎化, 导致各地雪豹及猎物种群被隔离, 遗传多样性下降, 增大孤 立小种群的灭绝风险。中国与西部各国的边境区域存在大量雪豹栖息地。大中型野生兽类几乎没有穿越边 境围栏的可能。比如, 在新疆与蒙古接壤的阿尔泰山脉地区, 边境围栏完全阻隔雪豹的移动, 导致国内的阿 尔泰雪豹种群岩岩可危(WWF)。牧场上用来划清产权的围栏也同样会阻碍野生有蹄类动物。Xu等(2008)认 为铁丝围栏使得栖息地片段化, 影响了野生有蹄类动物生存, 也是青海省昆仑山沟里地区雪豹种群的潜在 威胁。李娟(2012)通过廊道分析发现, 昆仑山和祁连山的雪豹种群可能受到青藏公路和青藏铁路的阻隔, 而 阿尔泰山和天山雪豹种群同样如此。在新疆东天山区域, 通往乌鲁木齐的国道和铁路阻隔了乌鲁木齐南山 和博格达峰之间的雪豹种群交流，而阿拉山口处修建的公路可能阻断了东天山与准格尔界山之间雪豹迁徙 的唯一通道(荒野新疆)。

\section{(3)盗猎和误杀导致的猎物种群减少}

由于缺少法律保护, 岩羊曾遭到大量猎杀, 供当地牧民食用以及出口。自 1958 年起, 青海省每年平均 出口 100,000-200,000 kg 的岩羊肉(Schaller et al, 1988)。2000 年前后，民间枪支上缴，对岩羊等雪豹猎物的 有意捕杀几乎消失。但是, 川西地区仍存在当地群众或外来人设置的猎套, 有些是针对岩羊, 更多是针对鹿 和戕(鹿角、鹿茸、槥香的收集)。巴塘县还存在公务人员持枪盗猎的现象, 不是出于经济目的, 而是为了娱

(1) 安妮 (2016) 青海省野生雪豹粪便中寄生虫种类的初探. 本科学位论文, 中国农业大学, 北京. 
李小雨, 肖凌云, 梁旭永, 程琛, 冯琛, 赵翔, 刘炎林, 市晓星, 何兵, 张常智, Justine Shanti Alexander, 邢睿, 黄亚慧, 阿旺久美, 谢然尼玛, 宋大昭, 黄巧雯, 扎西桑俄, 彭奎, 尹杭, 连新明, 杨欣, 李易, 施小刚, 杨创 明, 吕植. 中国雪豹的威胁与保护现状. 生物多样性, 2019, 27 (9): 932-942.

http://www.biodiversity-science.net/CN/10.17520/biods.2019026

乐、收藏、食用野味等“战利品狩猎” (山水自然保护中心)。

\section{(4)家畜竞争导致的猎物种群减少}

关于家畜和雪豹的野生猎物之间的竞争关系，国内外已经开展过大量研究。Mishra 等(2004)在印度拉 达克斯皮蒂峡谷的研究发现，重度放牧的草场地上生物量低，岩羊密度和冬季前后的幼母比显著降低。

Suryawanshi 等(2010)的研究发现, 在家畜密度较高的地区, 岩羊冬季被迫改变食性, 吃更多的双子叶植物, 而且春季幼母比大为降低。肖凌云(2017)在三江源地区的研究却发现, 家畜没有造成岩羊显著的密度或幼母 比下降。但新疆的北山羊会明显避开赶羊人的活动区域(新疆荒野)。在四川卧龙国家级自然保护区, 过度放 牧对当地野生有蹄类动物造成了威胁, 可能威胁到当地的雪豹种群。

\section{(5)猎物疾病}

有蹄类疫病会导致猎物种群数量的减少, 进而可能对雪豹等食肉动物的生存造成负面影响。在亚洲, 家畜侵占野生动物栖息地的情况很普遍。家畜很可能是野生有蹄类动物疾病感染蔓延的源头, 应成为疾病 监测的首要目标。另外, 家畜还会迫使野生有蹄类向山上迁移, 进入生存压力更大的次优栖息地, 导致疾病 造成的影响更为恶劣(Ostrowski \& Gilbert, 2016)。2007 年，巴基斯坦北部的岩羊种群爆发了一场疥螨，导致 上百只岩羊死亡。早在 1996 年, 牧民就第一次报告了这种疾病: 整年都有发生, 能感染雌雄岩羊和各个年 龄组，十年后岩羊种群还未能恢复(Dagleish et al, 2007)。1968-1971 年间, 在哈萨克斯坦的 Aksu-Zhabagly 保 护区, 大约 $80 \%$ 的北山羊种群被感染。此外, 乌兹别克斯坦和吉尔吉斯斯坦的恰特卡尔地区也爆发过螨病 (Fedosenko \& Blank, 2001)。2010 年秋, 在塔吉克斯坦 Hazratishoh 地区西南部, 爆发了山羊支原体肺炎, 杀 死了至少 64 只捻角山羊(Ostrowski et al, 2011)。2007 年 7-11 月, 西藏西南部爆发了一场小反刍兽疫, 主要 影响山羊和绵羊(Wang et al, 2009); 到 2007 年 10 月, 家畜和岩羊均爆发致命性小反刍兽疫(Bao et al, 2011)。 2014-2016 年, 新疆东天山区域爆发小反刍兽疫, 导致大量北山羊死亡(荒野新疆)。

\section{C. 政策和认知相关威胁}

\section{(1)普遍认知缺乏导致的政策不当}

在雪豹分布国, 无论是与雪豹比邻的当地人、城市中的公众, 还是政府部门, 普遍不了解雪豹面临的困 境, 也不清楚雪豹的保护价值。这些认知上的缺失, 一方面是因为数据和研究不充分, 另一方面是因为对已 知信息的宣传、沟通不足。认知缺失导致出台不恰当的政策，例如国家投资巨大的退牧还草工程。大量资金 用于围栏建设, 本意是通过产权划分避免“公地悲剧”, 通过划分轮休牧场和禁牧草地恢复退化的草场、保护 生物多样性, 但大量修建的围栏非但没有促进草地的保护, 反倒在某些地区加剧了草场退化(Li et al, 2017), 还可能威胁野生动物的生存。

\section{(2)政策实施不力}

雪豹分布区大都地处偏远、交通不便，且分布区人口相对比较贫困(Mishra et al, 2003)。即使有合适的 政策，由于资金、人力、交通等限制，依然可能存在政策实施不力、甚至压根无法正确实施的情况。Chen 等 (2016)描述了西藏自治区的野生动物肇事补偿政策在实施中出现的具体问题, 青海省也存在类似的问题(山 水自然保护中心)。纵然政府有补偿资金可供申请, 但由于事发地点大多交通、通信不便, 很多情况下, 群众 很难在规定时间内完成上报审核手续, 不得不放弃申领补偿。

\section{(3)缺乏跨省(境)合作}

雪豹栖息地沿各大山系分布，当然不以行政单元为边界。然而各地建立保护区、实施保护政策时却都 以行政单元为界, 跨保护区、跨行政边界的合作较为困难。在一国之内, 两省区之间都很难制定并实施统一 的保护规划, 更勿论跨国界的合作。保护区边界以外或省界地区, 往往由于距离偏远而疏于管理, 成为偷猎 的高发区。

\section{(4)基层保护部门能力不足}

雪豹栖息地所在的保护区，往往面临资金、人力不足的限制，也缺乏系统、有针对性的技能培训，以开 展雪豹及伴生物种的调查、监测与保护工作。四川的保护区算是走在全国前列, 但只有几个熊猫国家级保护 区受到了较为良好的技能培训, 可以独立地开展此类工作。然而四川的雪豹栖息地大多分布在熊猫保护区 外。西藏、青海等省区保护区地域辽阔, 人力极度缺乏，几乎不可能靠保护区人员完成当地的雪豹调查。 
李小雨, 肖凌云, 梁旭迏, 程琛, 冯琛, 赵翔, 刘炎林, 市晓星, 何兵, 张常智, Justine Shanti Alexander, 邢睿, 黄亚慧, 阿旺久美, 谢然尼玛, 宋大昭, 黄巧雯, 扎西桑俄, 彭奎, 尹杭, 连新明, 杨欣, 李易, 施小刚, 杨创 明, 吕植. 中国雪豹的威胁与保护现状. 生物多样性, 2019, 27 (9): 932-942.

http://www.biodiversity-science.net/CN/10.17520/biods.2019026

\section{(5)当地社区保护动力不足}

目前, 在中国的雪豹分布区, 绝大多数基层群众知道雪豹是保护动物, 知道杀死雪豹是违法的, 也普 遍具有朴素的生态观念。但长期以来, 在生计压力和现行保护管理体制下, 群众没有机会深度参与家乡的保 护工作, 对野生动物持负面态度, 基层内生的保护力量极其缺乏。在监管或补偿措施不到位的情况下, 负面 态度有可能快速转化为报复性猎杀或其他破坏自然栖息地的行为，对雪豹保护造成重大威胁。

\section{D. 间接威胁}

\section{(1)气候变化}

全球平均气温的上升和降水程度的改变非常明显。联合国政府间气候变化专门委员会(IPCC, 2007)评 估亚洲山区受到气候变化的影响似乎更加严重。随着气候变暖, 雪豹栖息地向更高纬度和更高海拔变迁 $(\mathrm{Li}$ et al, 2016); 横断山和喜马拉雅的很多区域将可能不再适宜雪豹生存, 树线上升将导致喜马拉雅地区约 30\% 的雪豹栖息地丧失(Forrest et al, 2012)，全球雪豹栖息地破碎化进一步加剧，并使雪豹面临与豹(Panthera pardus) 竞争的局面(Lovari et al, 2013)。气候变化对冻土(Xue et al, 2009; Yang et al, 2018)、冰川(Yao et al, 2013)、 草甸(Klein et al, 2007; Yu et al, 2010; Lehnert et al, 2016)产生的影响更为深远, 其中, 对西藏㒸塘区域的影响 非常巨大, 冰川和冻土层的融化加速了草场的退化, 进一步影响逐水草而居的有蹄类(Luo et al, 2015)和当地 牧民(Vince, 2010)。气候变化可能改变捕食者与被捕食者之间的空间相互作用, 导致雪豹和岩羊分布范围重 叠的降低(Aryal et al, 2016)。当牧民的生计受到气候变化的负面影响后, 将可能降低其对雪豹等大型食肉动 物的容忍度, 导致报复性猎杀等事件的发生。

\section{(2)人口增长和贫困}

人口增长及贫困、栖息地过度利用等问题, 与生物多样性保护通常紧密关联(Adams et al, 2004)。生物 多样性保护必须考虑社会问题, 以实现社会发展与生态系统保护的双赢; 从 20 世纪 80 年代开始, 这已逐渐 成为保护工作的主流模式(McShane \& Wells, 2004)。在雪豹分布区内, 人口增长和贫困问题会导致对草场的 过度利用、野生有蹄类的减少、人兽冲突激化等一系列问题(Mishra et al, 2001, 2003)。因此, 无论是政府还 是非政府组织，针对扶贫、生态补偿、替代生计、技能培训等方面的投入，都在保护工作中占很大部分。

\section{(3)流浪狗袭击雪豹及其猎物}

自由放养、无主流浪狗及野狗, 即并非永久拴着或在人为监控下的狗(不论是否有主人), 占全球狗只数 量的 75\% (http://www.wspa.org.uk/wspaswork/dogs/strayanimals/)。它们繁殖力旺盛、适应能力强。如果没有 妥善管理, 当狗进入野地、和野生动物的接触逐渐增多, 它们可能成为捕食者、猎物以及资源竞争者(Butler et al, 2004), 甚至可能主宰当地的生态系统(Wandeler et al, 1993)。由于藏獒市场崩溃, 青藏高原上的流浪狗 越来越多地出现在雪豹栖息地内。当地牧民常目击到狗与雪豹争夺食物资源, 对雪豹进行直接骚扰。同时, 作为疾病携带者和传播者, 流浪狗对整个食肉动物群落造成潜在威胁。相关的研究正在进行中(北京大学刘 铭玉)。

\section{(4)虫草/药草采挖造成的干扰}

在虫草产区，虫草采挖季节大量外来人员聚集于雪豹栖息地。除了直接干扰雪豹及其猎物种群，外来 人员还可能盗猎野生动物。如四川洛须县的真达乡，每年虫草季节会有少量偷盗猎(山水自然保护中心)。虫 草采挖季节与雪豹产息季时间重叠, 每年都有“草民”发现雪豹窝的事件。如果不加以妥善引导, 天性敏感的 带急雪豹可能会因为巢址暴露而搬迁, 增大了幼息被其他食肉动物捕食的风险。

另外, 有些地区居民对高山中药材(如贝母、芫活等)的采集较为严重。此外, 采药者砍烧柴火用于煮饭 和炕药材, 大量破坏高山草甸的地表植被, 从而可能导致岩羊等雪豹主要猎物数量减少。

\section{(5)道路建设与旅游开发项目}

在雪豹分布区中, 基础设施建设普遍发展迅速, 尤其在印度、中国、俄罗斯和哈萨克斯坦等经济高速 发展的国家。在新疆, 一些大型交通建设项目阻隔雪豹栖息地, 干扰效应明显。近几年, 新疆有多个正在实 施或计划中的公路及铁路项目横跨天山。施工活动直接改变了雪豹的栖息地利用, 使得红外相机连续几个 月捕捉不到雪豹影像(荒野新疆)。旅游开发同样可能造成威胁。在四川, 地方政府正在加快旅游设施建设, 游客数量递增, 原先连片的雪豹栖息地被不同程度地分割开来, 种群交流机会减少。2017 年, 当地保护区在 
李小雨, 肖凌云, 梁旭进, 程琛, 冯琛, 赵翔, 刘炎林, 市晓星, 何兵, 张常智, Justine Shanti Alexander, 邢睿, 黄亚慧, 阿旺久美, 谢然尼玛, 宋大昭, 黄巧雯, 扎西桑俄, 彭奎, 尹杭, 连新明, 杨欣, 李易, 施小刚, 杨创 明, 吕植. 中国雪豹的威胁与保护现状. 生物多样性, 2019, 27 (9): 932-942.

http://www.biodiversity-science.net/CN/10.17520/biods.2019026

四川小金双桥沟、长坪沟、海子沟雪豹栖息地的红外相机监测发现, 60 台红外相机中只有一个位点获取了 一张雪豹影像资料(四川卧龙国家级自然保护区)。

\section{(6)矿产与水电开发}

中国、蒙古、吉尔吉斯斯坦、俄罗斯和塔吉克斯坦等雪豹分布国的矿产、天然气和石油资源丰富(Baker et al, 2010)。蒙古南部戈壁、青藏高原和其他地区有分散但广泛分布的小规模金矿。矿业开采活动直接破坏 雪豹赖以生存的裸岩石山, 并增加盗猎风险, 还因为道路发展给原本偏远的地区带来新的威胁(Wingard \& Zahler, 2006)。新疆天山地区随处可见的矿业开采活动使当地雪豹种群更加破碎, 是当地雪豹面临的最大威 胁。所幸近年来, 环保督查活动大大遏止了这类活动发展。天然气和石油管道将天山地区的雪豹栖息地一分 为二, 包括哈萨克斯坦-中国边界区域到乌鲁木齐和兰州的天然气管道(G19, G31, G10), 以及被提议的到塔 里木盆地的路线将会分割雪豹的南北部种群(Jackson et al, 2013)。

\section{参考文献}

Adams WM, Aveling R, Brockington D, Dickson B, Elliott J, Hutton J, Roe D, Vira B, Wolmer W (2004) Biodiversity conservation and the eradication of poverty. Science, 306, 1146-1149.

Alexander J, Chen P, Damerell P, Youkui W, Hughes J, Shi K, Riordan P (2015) Human wildlife conflict involving large carnivores in Qilianshan, China and the minimal paw-print of snow leopards. Biological Conservation, 187, $1-9$.

Aryal A, Shrestha UB, Ji W, Ale SB, Shrestha S, Ingty T, Maraseni T, Cockfield G, Raubenheimer, D (2016) Predicting the distributions of predator (snow leopard) and prey (blue sheep) under climate change in the Himalaya. Ecology and Evolution, 6, 4065-4075.

Baker MS, Elias N, Guzmán E, Soto-Viruet Y (2010) Mineral facilities of Asia and the Pacific. http://pubs.usgs.gov/of/2010/1254/. (accessed on 2012-11-09)

Bao J, Wang Z, Li L, Wu X, Sang P, Wu G, Ding G, Suo L, Liu C, Wang J, Zhao W, Li J, Qi L (2011) Detection and genetic characterization of peste despetits ruminants virus in free-living bharals (Pseudois nayaur) in Tibet, China. Research in Veterinary Science, 90, 238-240.

Brown LR (2008) Plan B 3.0: Mobilizing to Save Civilization (substantially revised). WW Norton \& Company, New York.

Butler JRA, Du Toit JT, Bingham J (2004) Free-ranging domestic dogs (Canis familiaris) as predators and prey in rural Zimbabwe: Threats of competition and disease to large wild carnivores. Biological Conservation, 115, 369-378.

Chen P, Gao Y, Lee AT, Cering LL, Shi K, Clark SG (2016) Human-carnivore coexistence in Qomolangma (Mt. Everest) Nature Reserve, China: Patterns and compensation. Biological Conservation, 197, 18-26.

Dagleish MP, Qurban A, Powell RK, Butz D, Woodford MH (2007) Fatal Sarcoptes scabiei infection of blue sheep (Pseudois nayaur) in Pakistan. Journal of Wildlife Diseases, 43, 512-517.

EIA (2008) Skin Deep: The need for effective enforcement to combat the Asian big cat skin trade. In: The 57th Meeting of the CITES Standing Committee FIC Europe, Brussels.

EIA (2012) Briefing on snow leopards in illegal trade-Asia's forgotten cats. In: The 2nd Asian Ministerial Conference on Tiger Conservation, Bhutan.

Fedosenko AK, Blank DA (2001) Capra sibirica. Mammal Species, 675, 1-13.

Fix AS, Riordan DP, Hill HT, Gill MA, Evans EB (1989) Feline panleukopenia virus and subsequent canine distemper virus infection in two snow leopards (Panthera uncia). Journal of Zoo and Wildlife Medicine, 20, $273-281$.

Forrest JL, Wikramanayake E, Shrestha R, Areendran G, Gyeltshen K, Maheshwari A, Mazumdar S, Naidoo R, Thapa GJ, Thapa K (2012) Conservation and climate change: Assessing the vulnerability of snow leopard 
李小雨, 肖凌云, 梁旭进, 程琛, 冯琛, 赵翔, 刘炎林, 市晓星, 何兵, 张常智, Justine Shanti Alexander, 邢睿, 黄亚慧, 阿旺久美, 谢然尼玛, 宋大昭, 黄巧雯, 扎西桑俄, 彭奎, 尹杭, 连新明, 杨欣, 李晟, 施小刚, 杨创 明, 吕植. 中国雪豹的威胁与保护现状. 生物多样性, 2019, 27 (9): 932-942.

http://www.biodiversity-science.net/CN/10.17520/biods.2019026

habitat to treeline shift in the Himalaya. Biological Conservation, 150, 129-135.

Harris RB (2010) Rangeland degradation on the Qinghai-Tibetan Plateau: A review of the evidence of its magnitude and causes. Journal of Arid Environments, 74, 1-12.

Jackson RM, Mallon D, Sharma RK, Suryawanshi KS, Mishra C (2013) Snow Leopard Survival Strategy. Version 2013.1, Snow Leopard Network, Seattle.

Klein JA, Harte J, Zhao X (2007) Experimental warming, not grazing, decreases rangeland quality on the Tibetan Plateau. Ecological Applications, 17, 541-557.

Lehnert LW, Wesche K, Trachte K, Reudenbach C, Bendix J (2016) Climate variability rather than overstocking causes recent large-scale cover changes of Tibetan pastures. Scientific Reports, 6, 24367.

Li J (2012) Ecology and Conservation Strategy of Snow Leopard (Panthera uncia) in Sanjiangyuan Area on the Tibetan Plateau. PhD dissertation, Peking University, Beijing. (in Chinese with English abstract) [李娟 (2012) 青藏高原三江源地区雪豹(Panthera uncia) 的生态学研究及保护. 博士学位论文, 北京大学, 北京.]

Li J, Lü Z (2014) Snow leopard poaching and trade in China 2000-2013. Biological Conservation, 176, 207-211.

Li J, McCarthy TM, Wang H, Weckworth BV, Schaller GB, Mishra C, Lü Z, Beissinger SR (2016) Climate refugia of snow leopards in High Asia. Biological Conservation, 203, 188-196.

Li J, Yin H, Wang D, Jiagong Zhala, Lü Z (2013) Human-snow leopard conflicts in the Sanjiangyuan Region of the Tibetan Plateau. Biological Conservation, 166, 118-123.

Li L, Fassnacht FE, Storch I, Bürgi M (2017) Land-use regime shift triggered the recent degradation of alpine pastures in Nyanpo Yutse of the eastern Qinghai-Tibetan Plateau. Landscape Ecology, 8, 1-17.

Liu WL (1993) Brief history about conservation and utilization of wild animals on the Tibetan Plateau. Journal of Tibet University, 8(1), 45-49. (in Chinese) [刘务林 (1993) 西藏高原人类保护利用野生动物简史. 西藏大学 学报, 8(1), 45-49.]

Lovari S, Ventimiglia M, Minder I (2013) Food habits of two leopard species, competition, climate change and upper treeline: A way to the decrease of an endangered species. Ethology Ecology \& Evolution, 25, 305-318.

Luo Z, Jiang Z, Tang S (2015) Impacts of climate change on distributions and diversity of ungulates on the Tibetan Plateau. Ecological Applications, 25, 24-38.

Ma M (2012) Market prices for the tissues and organs of snow leopards in China. Selevinia, 516, 119-122.

Maheshwari A, Niraj SK (2018) Monitoring illegal trade in snow leopards: 2003-2014. Global Ecology and Conservation, 14, e00387.

McShane TO, Wells MP (2004) Getting Biodiversity Projects to Work: Towards More Effective Conservation and Development. Columbia University Press, New York.

Mishra C, Allen P, McCarthy T, Madhusudan MD, Bayarjargal A, Prins HHT (2003) The role of incentive programs in conserving the snow leopard. Conservation Biology, 17, 1512-1520.

Mishra C, Prins HHT, Wieren VSE (2001) Overstocking in the Trans-Himalayan rangelands of India. Environmental Conservation, 28, 279-283.

Mishra C, Wieren SEV, Ketner P, Heitkonig IMA, Prins HHT (2004) Competition between domestic livestock and wild bharal Pseudois nayaur in the Indian Trans-Himalaya. Journal of Applied Ecology, 41, 344-354.

Oli MK, Taylor IR, Rogers ME (1994) Snow leopard (Panthera uncia) predation of livestock: An assessment of local perceptions in the Annapurna Conservation Area, Nepal. Biological Conservation, 68, 63-68.

Ostrowski S, Gilbert M (2016) Diseases of free-ranging snow leopards and primary prey species. In: Snow Leopard (eds McCarthy T, Mallon D), pp. 97-112. Academic Press, London.

Ostrowski S, Thiaucourt F, Amirbekov M, Mahmadshoev A, Manso-Silván L, Dupuy V, Vahobov D, Ziyoev O, Michel S (2011) Fatal outbreak of Mycoplasma capricolum pneumonia in endangered markhors. Emerging Infectious Disease, 17, 2338-2341. 
李小雨, 肖凌云, 梁旭进, 程琛, 冯琛, 赵翔, 刘炎林, 市晓星, 何兵, 张常智, Justine Shanti Alexander, 邢睿, 黄亚慧, 阿旺久美, 谢然尼玛, 宋大昭, 黄巧雯, 扎西桑俄, 彭奎, 尹杭, 连新明, 杨欣, 李易, 施小刚, 杨创 明, 吕植. 中国雪豹的威胁与保护现状. 生物多样性, 2019, 27 (9): 932-942.

http://www.biodiversity-science.net/CN/10.17520/biods.2019026

Peng JT (2009) An investigation on snow leopard resources in Ganzi Prefecture in the Hengduan Mountains on the southeast of the Qinghai-Tibet Plateau. Journal of Sichuan Forestry Science and Technology, 30(1), 57-58, 47. (in Chinese with English abstract) [彭基泰 (2009) 青藏高原东南横断山脉甘孜地区雪豹资源调查研究. 四 川林业科技, 30(1), 57-58, 47.]

Schaller GB, Junrang R, Mingjiang Q (1988) Status of the snow leopard (Panthera uncia) in Qinghai and Gansu provinces, China. Biological Conservation, 45, 179-194.

Silinski S, Robert N, Walzer C (2003) Canine distemper and toxoplasmosis in a captive snow leopard (Uncia uncia) -A diagnostic dilemma. Verhandlungsbericht des Symposium uber die Erkrankungen der Zootiere, 41, 107-111.

Suryawanshi KR, Bhatnagar YV, Mishra C (2010) Why should a grazer browse? Livestock impact on winter resource use by bharal Pseudois nayaur. Oecologia, 162, 453-462.

Vince G (2010) A himalaya village builds artificial glaciers to survive global warming. Scientific American.

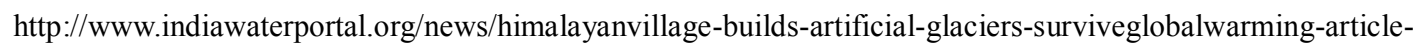
scientific-american. (accessed on 2012-09-11)

Wandeler A, Matter H, Kappeler A, Budde A (1993) The ecology of dogs and canine rabies: A selective review. Revue Scientifique et Technique (International Office of Epizootics), 12(1), 51-71.

Wang P, Lassoie JP, Morreale SJ, Dong S (2015) A critical review of socioeconomic and natural factors in ecological degradation on the Qinghai-Tibetan Plateau, China. The Rangeland Journal, 37, 1-9.

Wang Z, Bao J, Wu X, Liu Y, Li L, Liu C, Suo L, Xie Z, Zhao W, Zhang W, Yang N, Li J, Wang S, Wang J (2009) Peste des petits ruminants virus in Tibet, China. Emerging Infectious Disease, 15, 299-301.

Wingard JR, Zahler P (2006) Silent Steppe: The Illegal Wildlife Trade Crisis in Mongolia. Discussion Paper, East Asia and Pacific Environmental and Social Development Department World Bank, Mongolia and Washington, DC.

Xiao LY (2017) The Interaction Among Snow Leopards (Panthera uncia), Blue Sheep (Pseudois nayaur) and Livestock in Sanjiangyuan Region. PhD dissertation, Peking University, Beijing. (in Chinese with English abstract) [肖凌云 (2017) 三江源地区雪豹(Panthera uncia)、岩羊(Pseudois nayaur)与家畜的竞争与捕食关 系研究. 博士学位论文, 北京大学, 北京.]

Xu A, Jiang Z, Li C, Guo J, Da S, Cui Q, Yu S, Wu G (2008) Status and conservation of the snow leopard Panthera uncia in the Gouli Region, Kunlun Mountains, China. Oryx, 42, 460-463.

Xue X, Guo J, Han B, Sun Q, Liu L (2009) The effect of climate warming and permafrost thaw on desertification in the Qinghai-Tibetan Plateau. Geomorphology, 108, 182-190.

Yang Y, Hopping K, Wang G, Chen J, Peng A, Klein JA (2018) Permafrost and drought regulate vulnerability of Tibetan Plateau grasslands to warming. Ecosphere, 9, e02233.

Yao T, Wang Y, Liu S, Pu J, Shen Y, Lu A (2013) Recent glacial retreat in High Asia in China and its impact on water resource in Northwest China. Science in China, 47, 1065-1075.

Yu H, Luedeling E, Xu J (2010) Winter and spring warming result in delayed spring phenology on the Tibetan Plateau. Proceedings of the National Academy of Sciences, USA, 107, 22151-22156.

Zhang DM (1985) The dynamics of a few animals during the last thirty years in Ili Prefecture, Xinjiang Uygur Autonomous Region. Acta Theriologica Sinica, 5, 56, 66. (in Chinese) [张大铭 (1985) 新疆伊犁地区近三十 年来几种兽类的动态. 兽类学报, $5,56,66$.] 
李小雨, 肖凌云, 梁旭进, 程琛, 冯琛, 赵翔, 刘炎林, 市晓星, 何兵, 张常智, Justine Shanti Alexander, 邢睿, 黄亚慧, 阿旺久美, 谢然尼玛, 宋大昭, 黄巧雯, 扎西桑俄, 彭奎, 尹杭, 连新明, 杨欣, 李易, 施小刚, 杨创 明, 吕植. 中国雪豹的威胁与保护现状. 生物多样性, 2019, 27 (9): 932-942.

http://www.biodiversity-science.net/CN/10.17520/biods.2019026

\section{附录3 国内已有的雪豹保护行动案例}

Appendix 3 Existing snow leopard protective actions in China

这里列举了比较具有各地特征性的保护案例(没有列出国外有而国内尚未开展的保护行动), 以及全国 范围内惠及雪豹的政策, 如野生动物立法执法、家畜疫病防治、精准扶贫、生态补偿(如草原生态奖补)等, 这 些政策作为大背景，为雪豹保护提供了最根本的保障。

\section{A. 保护地建设}

\section{(1)保护区监测与反盗猎巡护}

行动主体: 四川省林业厅、卧龙国家级自然保护区、北京大学野生动物生态与保护研究组

自 2016 年起, 北京大学联合绵阳师范学院等单位，与邛崃山区内各自然保护区协调，在邛崃山中部合 作建成区域性红外相机监测网络。通过野外实地调查并借助红外相机, 该项工作在扔崃山雪豹栖息地内及 周边记录到大量的人为活动, 主要包括 5 类: 放牧、采集、偷猎、旅游与基础设施建设。其中前 3 类活动大 多位于自然保护区的核心区，均为非法进入自然保护区开展的活动。根据监测结果和威胁评估，各保护区相 继开展了针对性的保护行动。网络建成以来, 当地保护区对于野生动物状况的了解取得了长足的进步。

2017 年 11 月, 卧龙国家级自然保护区和四川省林业厅牵头, 在都江堰召开了“首届横断山雪豹保护行 动研讨会”, 并发布“卧龙雪豹宣言”。在研讨会上, 北京大学生命科学学院与卧龙国家级自然保护区签署了 共同开展雪豹研究与保护的合作协议。合作以来, 北京大学研究团队基于监测网络的数据取得了当地雪豹 潜在猎物与多度、雪豹种群数量、雪豹食性等重要成果。

\section{(2)保护区能力建设}

行动主体: 三江源国家公园管理局

2016 年三江源国家公园建设试点工作启动以来, 三江源国家公园共招聘了 16,421 名牧民作为国家公 园生态管护公益岗位, 实现了国家公园区域内一户一岗, 有效补充了保护能力的不足。针对生态管护公益岗 位，三江源国家公园管理局两年来共投入超过 2,000 万元开展培训，邀请相关专家以及山水自然保护中心等 机构参与。培训内容覆盖环境政策和法律、红外相机监测、反盗猎巡护、生物多样性知识等内容, 有效地提 升了当地保护力量。

\section{(3)建立新保护地}

行动主体: 天山东部国有林管理局、荒野新疆

2014-2018 年间, 荒野新疆在乌鲁木齐南山项目地持续监测当地雪豹种群。2016 年, 荒野新疆在天山 东部国有林管理局的支持下, 联合山水自然保护中心、中国绿发会等民间保护组织, 在乌鲁木齐南山雪豹项 目地设立了第一座监测保护站，建立新疆第一个雪豹保护地“乌鲁木齐河雪豹保护地”, 同期还构建起两个 林业管护所和 20 户牧民组成的社区监测保护网络。

该保护地以“林业管理部门牵头，民间保护力量参与”为原则，以乌鲁木齐河水源地保护区域范围为核 心, 开展雪豹监测、反盗猎巡护、社区保护宣讲、缓解人兽冲突、公众环境教育等工作。

随着保护地工作的不断开展, 目前社区牧民普遍对雪豹保护工作表示理解和支持, 人兽冲突得到有效 缓解, 2 年内未发生野生动物盗猎事件。2018 年 8 月, 该区域污染企业全部搬迁, 最后两个矿点停产。通过 总结保护地的试点经验, 天山东部国有林管理局目前已经制定了在辖区内的十一个分局展开雪豹调查和管 理能力建设的计划, 力争在 2020 年申请成立东天山国家公园。

\section{B. 在地保护行动}

\section{(1)人兽冲突补偿}

行动主体: 三江源国家公园澜沧江源园区管委会、山水自然保护中心

前期调查显示, 2015 年昂赛乡年都村平均每户有 4.6 头牛被雪豹、金钱豹、然、狼等捕食, 户均损失超 过 5,000 元, 最多的一户达到 23 头。人兽冲突是生态问题，存在激发牧民报复性猎杀的风险; 同时也是民生 问题, 牧民因此承受着较大的损失。解决人兽冲突, 需要提高牧民事前防范能力并提供事后补偿。

从 2016 年起，山水自然保护中心和三江源国家公园澜沧江源园区管委会合作，开展人兽冲突补偿试点 行动。在项目支持下，山水自然保护中心与杂多县政府分别投入 10 万元，牧民为每头牛投保 3 元，建立共 计 24 万元的“澜沧江源人兽冲突补偿基金”。截至 2017 年 12 月, 该基金共补偿 222 起野生动物肇事, 共计 
李小雨, 肖凌云, 梁旭永, 程琛, 冯琛, 赵翔, 刘炎林, 市晓星, 何兵, 张常智, Justine Shanti Alexander, 邢睿, 黄亚慧, 阿旺久美, 谢然尼玛, 宋大昭, 黄巧雯, 扎西桑俄, 彭奎, 尹杭, 连新明, 杨欣, 李易, 施小刚, 杨创 明, 吕植. 中国雪豹的威胁与保护现状. 生物多样性, 2019, 27 (9): 932-942.

http://www.biodiversity-science.net/CN/10.17520/biods.2019026

金额 22 万元。在向三江源国家公园管理局提交第一期人兽冲突基金报告后，该项目获得了 2018 年昂赛三 个村共计 30 万的基金配套资金。相关模式有望在整个三江源区域内推广。

澜沧江人兽冲突保险基金有两个创新点。第一，下放管理权利，简化审核流程，以社区为主体制定补偿 策略, 进行补偿核实工作。这降低了补偿核实成本, 群众充分受益。第二, 基金管理委员会制订规则, 牧民 需承担对家畜的管护责任。因为管护不到位导致的家畜损失，基金不予补偿。

\section{(2)社区监测与反盗猎巡护}

行动主体: 西藏自治区林业厅、国际野生生物保护协会(WCS)

2016 年, 在西藏自治区林业厅的支持下, 申扎县启动雪豹研究与保护项目。县林业局选拔 6 名牧民野 生动物保护员参加该项工作, 并与 WCS 合作。WCS 对牧民野保员开展大量理论与实践培训, 包括雪豹痕 迹识别、红外相机使用、GPS 坐标系统、野外调查设计。最初, 6 名野保员只是承担野外向导等辅助角色, 但 很快成为监测工作的主力。目前, 他们已完全承担起 $2,000 \mathrm{~km}^{2}$ 的红外相机监测网络维护以及猎物调查任务, 并协助美塘保护区开展红外相机监测以及保护区管护员的培训。此外, 他们正在学习雪豹个体识别和数据 库管理。另外, 作为试点, 6 名野保员正在现代化巡护系统的支撑下开展网格化巡护, 并参与构建当地野生 动物救助体系。同时, 这 6 名野保员在巡护监测之余, 在县林业局和社会资源的支持下，向乡亲们积极宣传 野保理念, 组织社区环境治理活动, 建设食肉猛兽防护设施。作为平均文化程度不到初中水平的普通牧民, 他们的表现充分说明: 社区群众完全有能力在家乡野生动物保护的进程中担负更重要的角色。

\section{(3)科学志愿者监测与反盗猎巡护}

行动主体: 荒野新疆、天山东部国有林管理局

“荒野新疆”是新疆乌鲁木齐的民间动物保护组织。借助志愿者网络, 荒野新疆对新疆的主要雪豹栖息 地进行了多年的调查监测, 评估了雪豹种群扩散的廊道。2014-2018 年间, 在天山东部国有林管理局的管理 和支持下, 荒野新疆对乌鲁木齐郊区 $600 \mathrm{~km}^{2}$ 区域持续开展雪豹种群调查和监测, 建立起超过 60 只个体的 雪豹个体影像库, 并对该区域的雪豹种群状况、威胁因素、保护策略进行分析和建议。荒野新疆还联合森林 公安部门开展普法宣讲, 配合公安部门抓捕盗猎团伙, 并长期义务承担起野外巡护的任务。几年间, 累计有 数百名志愿者参与到乌鲁木齐雪豹保护行动中。他们在线上宣传雪豹保护, 在线下参与野外工作。相关媒体 报道上百次, 并拍摄多部纪录片在央视等平台播出。乌鲁木齐市民及新疆人民对雪豹已经具有一定自豪感。 荒野新疆的工作大大提升了雪豹保护的社会关注度, 为发展新疆的野生动物保护事业创造了良好氛围。

\section{(4)扶贫/生计改善}

\section{i. 手工艺品}

行动主体: 全球环境研究所(GEI)

作为三江源社区的典型代表, 近年来年保玉则隆格村面临着草地退化、人地关系紧张、不规范的旅游 破坏以及资源单一发展受限等因素的影响。为应对这些威胁, 全球环境研究所(GEI)引入了社区协议保护机 制。

GEI 促进隆格村与三江源自然保护区签订保护协议，将部分保护权赋予社区，约定权利、责任和利益。 GEI 和保护区协助社区成立自己的巡护队伍并制定社区管护计划, 提供保护方法和工具, 开展巡护、环境监 测和水源清洁等系列生态保护行动。同时, GEI 与保护区和社区分别签订项目协议, 成立属于社区的保护与 发展基金。基金及其贷款利息一方面支持社区成立合作社，制定可持续生计计划，比如发展负责任的生态旅 游服务, 培训牧民发展传统手工艺, 开发生态友好产品。相关收益的 $25 \%$ 必须投入到社区保护工作。另一方 面, GEI 邀请相关专家为社区开展培训, 包括巡护和监测技能, 协助产品设计开发、宣传推广和商业拓展的 能力建设。协议保护机制使社区从保护中获益, 成为一个相互嵌套不可分割的长效保护机制。

另外, GEI 借鉴保护国际及其他机构的评价指标，建立一套对社区协议保护地的评价指标体系，包括生 态效益、经济效益和社会效益三大类别, 并邀请第三方进行评估。目前, 隆格村草场管理趋于合理, 生态改 善明显。保护地内盗猎大量减少。鸟类栖息地环境得到有效维护, 湿地湖泊水源垃圾消失, 游客干扰野生动 物的行为逐年减少。社区基金由 5 万增长到 7 万, 贷款支持了合作社 20 多户牧民生计发展; 依靠生态旅游 和手工艺, 目前牧民平均收入增加了 $1-1.5$ 倍。 
李小雨, 肖凌云, 梁旭进, 程琛, 冯琛, 赵翔, 刘炎林, 市晓星, 何兵, 张常智, Justine Shanti Alexander, 邢睿, 黄亚慧, 阿旺久美, 谢然尼玛, 宋大昭, 黄巧雯, 扎西桑俄, 彭奎, 尹杭, 连新明, 杨欣, 李易, 施小刚, 杨创 明, 吕植. 中国雪豹的威胁与保护现状. 生物多样性, 2019, 27 (9): 932-942.

http://www.biodiversity-science.net/CN/10.17520/biods.2019026

社区凝聚力明显增强, 社区关系实现了重构, 实现公共资源的共同管理。社区适应气候变化的能力明 显增强，弹性增加。隆格村的模式已经成为青海省牧民社区的典范之一。

\section{ii. 自然体验}

行动主体: 三江源国家公园澜沧江源园区管委会、山水自然保护中心

雪豹保护需要社区的长期参与。让社区从保护雪豹中直接受益, 保持持续的动力尤为重要。2015 年, 在三江源国家公园内的昂赛管护站，山水自然保护中心与国家公园管理局合作，基于红外相机监测以及人 兽冲突的审核数据, 开发了雪豹自然体验产品。通过特许经营权的运作, 培训了 23 户当地牧民接待家庭, 设 计了 5 条雪豹自然体验路线。项目设计了预约网站: https://valleyofthecats.org/。至今, 昂赛已经接待了 60 多 个国内外自然体验团, 户均增收超过 6,000 元。

在所有的收入中, $45 \%$ 归接待家庭, $45 \%$ 归村集体所有, $10 \%$ 投入社区人兽冲突基金。项目希望充分构建 自然体验与社区保护之间的关系, 实现社区保护的集体行动。

\section{(5)放牧管理和拆除围栏}

行动主体: 三江源生态保护协会

甘达村位于玉树市西部, 是玉树州州府街古镇重要的水源地。全村有超过 370 户村民, 但是只有 9 万 5 千多亩草场。三江源生态保护协会通过与社区讨论, 把全村划为 23 个社区综合保护地, 并成立由村委会、 寺院、乡政府、民间组织、学校共同组成的自然资源管理委员会, 根据保护地的环境状况来制定管理制度及 工作计划, 再由牧民推选出一个能代表他们的组长。

由于草场面积小, 1984 年甘达村并没有把草场分配到户。围栏项目来了之后, 牧民自行购买围栏, 围上 了家里经常放牧的草场。协会在进行社区访谈时发现村子中最大的矛盾是围栏：围栏的位置、牲畜迁移时 的不便等造成了各种各样的问题。2017 年, 在村委会、共管委员会、协会的共同推动下, 甘达村自愿拆除了 草场上所有的围栏, 牧户之间的矛盾得到了化解, 村中的氛围也变得融洽。牧民们说: 之前看到就连嘎松舟 神山都围满了围栏，其实心里是不开心的，拆除了围栏，觉得家乡“土地的灵气”都完全不同了。

\section{(6)流浪狗管理}

行动主体: 青海雪境生态宣传教育与研究中心

2014 年至今, 青海雪境生态宣传教育与研究中心针对高原流浪狗问题进行实地调研, 发现高原流浪狗 对于野生动物以及社区民生安全的影响非常严重, 而且成因很多。因此, 针对问题的复杂性, 雪境主张开展 绝育、推动就地“领养”、宣传疾病预防和绝育、争取社会各界的捐助与支持。

2017 年 6 月, 在果洛州久治县白玉寺的大力推动、爱心企业的热心资助和外地兽医志愿者的技术支持 下, 项目成功地完成了 26 只母犬的绝育手术。项目同时开展本地兽医培训工作, 通过把绝育设备和药品发 放给技术成熟的本地兽医, 大大推进了绝育速度。项目还鼓励社区领养流浪犬, 流浪犬在成为有主犬之后更 有利于绝育, 可以从源头上控制包虫病的传播。冊庸置疑, 当地社区的大力支持让流浪狗管理在藏族聚居区 成为可能。

\section{(7)虫草采集管理}

行动主体: 山水自然保护中心

虫草资源已成为青藏高原社区最重要的资源, 带来了巨大的经济收益。从 2011 年起, 山水自然保护中 心持续观察玉树市云塔村的虫草采挖, 希望通过调查虫草这一公共资源的管理, 增加对于青藏高原传统社 区管理制度的了解。

在虫草时节, 云塔村成立自己的虫草管理小组, 主要由村支书、社长、社会计以及 9 个小组长等 12 人 组成。为了实现可持续采集，管理小组制定了一整套的措施，诸如控制外来人口、垃圾管理、不能乱砍薪柴 等, 取得了非常好的成效。

从云塔的案例可以看出, 对于像虫草这样的自然资源以及生态保护这样的公共事务, 应该充分借助现 有的社区管理体制, 形成以社区为主体的自然资源和公共事务管理模式。考虑到社区的复杂性以及社区居 民本身自己的管理意愿，应当以传统的村社作为资源的管理单元。

\section{(8)社区宣传教育}


李小雨, 肖凌云, 梁旭永, 程琛, 冯琛, 赵翔, 刘炎林, 市晓星, 何兵, 张常智, Justine Shanti Alexander, 邢睿, 黄亚慧, 阿旺久美, 谢然尼玛, 宋大昭, 黄巧雯, 扎西桑俄, 彭奎, 尹杭, 连新明, 杨欣, 李易, 施小刚, 杨创 明, 吕植. 中国雪豹的威胁与保护现状. 生物多样性, 2019, 27 (9): 932-942.

http://www.biodiversity-science.net/CN/10.17520/biods.2019026

行动主体: 年保玉则生态环境保护协会

2009 年开始, 年保玉则生态环境保护协会(简称“年措”)持续开展雪豹保护工作。早期，因为山上有足 够的野生动物吃, 雪豹很少下到牧民与家畜活动的范围, 所以老百姓以为雪豹是一种非常罕见而神秘的动 物。由于 20 世纪末青海大规模猎杀野生动物, 雪豹才开始大量捕食家畜, 本世纪初当地也时而出现报复性 猎杀。

在北京大学、山水自然保护中心、乔治·夏勒博士等机构与个人的支持下, 2011 年, 年措开展详细调查, 涉及 400 余户牧民, 布设大量红外相机。他们推算年保玉则分布有 40 余只雪豹, 人兽冲突加剧与 20 世纪对 雪豹自然猎物的过度猎杀有关。2011 年起, 年措对当地牧民开展有针对性的雪豹保护宣传教育活动。年保 玉则的“乡村之眼”团队共拍摄三部以雪豹监测和与牧民的冲突为主题的纪录片, 并在年措组织的“乡村电影 节”上多次放映, 观众近千。2014 年, 年措举办红外相机雪豹摄影大赛, 参赛者均为当地老百姓。年措还为 保护雪豹贡献最突出的三家牧户颁奖, 感谢他们在自家牛、羊长期被雪豹捕食的处境下仍支持这一珍稀物 种的保护，并在各个社区集会时为他们颁发“保护雪豹”证书，让他们的付出得到更多人的认可。

多年来, 年措坚持开展面向群众的保护知识培训, 当地百姓参与超过 2,000 人次。由于“众生平等” 的 信仰, 群众不理解为什么要特殊保护雪豹, 年措就从当地群众容易理解接受的宣传角度出发: 雪豹是国家 保护动物，比较受重视，保护它们能得到更多政策和资金的支持。保护雪豹就是保护它们居住的地方，也就 保护了以年保玉则为家园的大大小小许多生命。

当地社区与科学家合作, 年保玉则雪豹的生存现状得到了更好的了解。借助佛教思想鼓励当地老百姓 “护生”, 年保玉则的雪豹种群得到了有效的保护。

\section{C. 政策与公众推动}

\section{(1)管理开发、发展类项目}

行动主体: 绿色江河、中国科学院西北高原研究所

烟瘴挂是长江上游第一个大峡谷, 是整个长江流域原生环境保存最为完好的净土。但是, 烟瘴挂一度 可能成为水电站建设的牺牲品。如果规划中的牙哥水电站变成现实, 万里长江之上再无一段纯自然的河道。 在措池村和当地寺院的帮助下, 绿色江河在 $10 \mathrm{~km}$ 长的烟瘴挂峡谷内架设了 39 台红外照相机。通过 5 个月 监测, 在不足 $40 \mathrm{~km}^{2}$ 的范围内, 共拍摄到 9-14 只雪豹个体, 同时岩羊、白唇鹿、兔狲、棕熊、石貂、马麇、 狼、猞猁、赤狐等其他动物的精彩画面也越来越多。而且, 烟瘴挂峡谷中沟壑纵横, 分布着非常丰富的植被 类型, 包括草原、草甸、山谷草甸、谷坡灌从等。特殊的岩石地貌把周边降水蓄积到峡谷内部, 更有利于牧 草的发育。这里以针茅、嵩草、苔草为主的草地质量非常高: 面积虽然不大, 但生产力很高, 能够养活数量 较大的食草动物。大量的数据、图片、影像记录并展示了峡谷内丰富的生物多样性和外围的文化多样性。

绿色江河借助这些信息完成调查报告, 提交给政府部门。青海省发改委高度肯定报告内容, 并明确表 示: 在生物多样性如此丰富的烟瘴挂地区, 绝不允许建设水电站。在此基础上, 绿色江河希望帮助当地社区 设计规划小规模的参与式、科考式旅游, 建立社区自治共管模式, 为当地的可持续发展提供一种路径, 使烟 瘴挂自然和人文生态得到最好保护。

\section{(2)公众传播}

行动主体: 西宁市动物园 齐新章

在新媒体快速发展的今天, 通过微博、微信搭建平台, 增加公众对于雪豹研究和保护的了解已经成为 非常重要的方法, 几乎每家机构都会在自己的工作中有所涉及。

其中, 西宁动物园副园长齐新章, 微博名“圆掌”, 从 2017 年开始, 基于凌雪、凌霜两只野外雪豹的救 助，在微博上发起了“雪豹救护”超级话题，通过实时更新雪豹救助和恢复的动态，目前共发布了 352 条帖子， 获得了 1.2 亿人次的阅读量。除了雪豹救护之外，根据目前唯一人工繁育的雪豹傲雪所发起的超级话题“傲 雪公主”, 也获得 2,600 万人次的阅读量。通过微博的传播, 公众已捐助了 209 批物资, 用于支持动物园丰容 等工作，总价值达到 13 万元。

诸如微博这样的新媒体, 在极大地增加公众对于雪豹了解的同时, 展现了动物园救护雪豹的全过程, 很好地树立了政府部门在野生动物救助上的形象和能力, 并构建了公众参与野生动物保护的平台。 
李小雨, 肖凌云, 梁旭进, 程琛, 冯琛, 赵翔, 刘炎林, 市晓星, 何兵, 张常智, Justine Shanti Alexander, 邢睿, 黄亚慧, 阿旺久美, 谢然尼玛, 宋大昭, 黄巧雯, 扎西桑俄, 彭奎, 尹杭, 连新明, 杨欣, 李晟, 施小刚, 杨创 明, 吕植. 中国雪豹的威胁与保护现状. 生物多样性, 2019, 27 (9): 932-942.

http://www.biodiversity-science.net/CN/10.17520/biods.2019026

\section{(3)政策建议}

行动主体: 三江源国家公园管理局、阿拉善 SEE 基金会、山水自然保护中心

阿拉善 SEE 基金会、山水自然保护中心自 2012 年开始战略合作，推动三江源生态保护工作。从 2011 年开始, 阿拉善 SEE 基金会与山水自然保护中心联合青海省法制办、青海省委党校等机构, 主办了四期“三 江源论坛”, 汇集了三江源重要的政府领导和保护相关部门，以及重要的学者及民间机构。论坛的一个重要 产出, 就是对三江源的立法进行研究和政策倡导, 出台了《青海三江源生态保护管理办法》。同时, 项目组也 参与了《三江源国家公园条例》以及《青海省重点保护陆生野生动物造成人身财产损失补偿办法》修订的 专家顾问团, 贡献意见和建议。

在三江源国家公园澜沧江园区的昂赛乡，阿拉善 SEE 基金会、山水自然保护中心、北京大学与三江源 国家公园共建了昂赛保护站, 推动在地的科学研究和保护工作。山水与青海省委党校、杂多县政府合作, 向 青海省委、省政府联合提交了《关于进一步做好三江源雪豹保护的建议》。2016 年 8 月, 合作伙伴中共杂多 县委才旦周书记在昂赛通过视频连线向习近平总书记汇报了昂赛的国家公园试点工作, 并着重介绍了当地 雪豹研究和保护进展, 得到总书记的肯定和赞许。

\section{(4)保护规划制定}

行动主体: 国家林业和草原局、青海省林业厅、甘肃省林业厅

国家林业和草原局已经委托北京林业大学制定了中国雪豹保护规划。除此之外，青海省林业厅委托中 国林业科学研究院正在制定省级的保护规划，而甘肃省的雪豹保护规划由世界自然基金会(WWF)协助制定。 在地方层面, 玉树州杂多县委托山水自然保护中心在完成了全县 $20 \%$ 的抽样面积的基础上, 制定了县级雪 豹保护规划。 